HID 46 (2019)

\title{
LAS RELACIONES MURCIA-ORIHUELA EN LA PRIMERA MITAD DEL SIGLO XIV (1304-1355)
}

\author{
MURCIA-ORIHUELA RELATIONSHIPS IN THE FIRST HALF OF THE \\ $14^{\mathrm{TH}}$ CENTURY (1304-1355)
}

\author{
Francisco de Asís Veas Arteseros \\ Universidad de Murcia \\ franveas@um.es ORCID: https://orcid.org/0000-0001-7929-2699
}

RESUMEN: La Sentencia de Torrellas (1304) rompió definitivamente la unidad geográfica y geopolítica que hasta ese momento habían mantenido las tierras emplazadas a lo largo del curso del río Segura, cuyo tramo final, la denominada "Vega Baja", pasó a formar parte del reino de Aragón y muy poco tiempo después nacía la Gobernación de Orihuela, situada en el flanco sur del reino de Valencia y fronteriza con las tierras castellanas del reino de Murcia, formada por esos territorios que anteriormente habían pertenecido al adelantamiento murciano. Desde entonces se producirán fases de crispación en las relaciones entre los habitantes de uno y otro lado de la frontera imprecisa trazada en aplicación de la sentencia, que afectan también al plano eclesiástico a causa del anacronismo que suponía que la aragonesa Gobernación de Orihuela perteneciese al obispado de Cartagena, una sede castellana.

Palabras ClaVE: Murcia; Orihuela; Torrellas; agua; quema; Obispado de Cartagena.

ABSTRACT: The Sentence of Torrellas (1304) definitely broke the geographic and geopolitical unity that the lands emplaced along the course of the Segura had maintained, whose final section, the so called "Vega Baja", became part of the Kingdom of Aragon and very little after the Governance of Orihuela, located on the southern flank of the Kingdom of Valencia and bordering with the Castilian lands of the Kingdom of Murcia, formed by those territories that previously belonged to the adelantamiento of Murcia. Since then several phases of tension in the

Recibido: 18-11-2018; Aceptado: 1-4-2019; Versión definitiva: 6-4-2019.

1. Abreviaturas utilizadas: $\mathrm{AMM}=$ Archivo Municipal de Murcia; $\mathrm{AC}=\mathrm{Acta}$ Capitular; $\mathrm{AMO}=$ Archivo Municipal de Orihuela; Doc = Documento; Ed = Edición; LA = Libro de Actas; Pg = Pergamino; $\mathrm{RAH}=$ Real Academia de la Historia.

Copyright: (C) Editorial Universidad de Sevilla. Este es un artículo de acceso abierto distribuido bajo los términos de la licencia de uso y distribución Creative Commons Reconocimiento-No-ComercialSinObraDerivada 4.0 (CC BY-NC-ND 4.0) 
relations between the inhabitants from both sides of the imprecisely traced frontier on application of the sentence happened, which also affect the ecclesiastical plane due to the anachronism that the Governance of Orihuela belonged to the Bishopric of Cartagena, a Castilian see, entailed.

KEYWORDS: Murcia; Orihuela; Torrellas; water; burn; Bishopric of Cartagena.

Muchas veces en la historia la resolución de un conflicto es el origen de otro u otros que hasta entonces no habían existido y un ejemplo de lo dicho fue la Sentencia Arbitral de Torrellas ${ }^{2}$, pues si acabó con la ocupación aragonesa del reino de Murcia, también impuso la segregación de una gran parte de lo que hasta entonces había sido su territorio para compensar a Jaime II, derrotado en sus pretensiones de anular el Tratado de Almizra, por olvidarse para siempre de que Aragón tuviese frontera terrestre con Granada, aunque será ésta una cuestión recurrente y Pedro IV tratará con Enrique de Trastámara la entrega del reino de Murcia a cambio de la ayuda que le prestaba para luchar contra Pedro I, aunque, ya rey de Castilla, Enrique II se negó ${ }^{3}$.

Torrellas fue una arbitrariedad permitida por la inoperancia y debilidad de Fernando IV y no fue completa porque la rectificación de Elche, en 1305, devolvió

2. 1304-VIII-8, Torrellas. Torres Fontes 1969. Doc. CLIII.

3. En aquellos momentos de la guerra entre Enrique de Trástámara y Pedro I en los que el primero necesitaba más apoyo, Pedro IV de Aragón jugó la carta de reconocer a Enrique como rey de Castilla y ambos suscribieron el Tratado de Binéfar, el 6 de octubre de 1363, por el cual, en caso de que el conde de Trastámara acabase sentado en el trono castellano, debería entregar a su aliado el reino de Murcia y las ciudades de Utiel, Moya, Cañete, Cuenca, Molina, Soria, Medinaceli, Ágreda y Almazán, y en garantía del cumplimiento del pacto Juan, primogénito de Enrique, fue enviado a la corte aragonesa y Alfonso, el menor de los hijos de Pedro IV, se incorporó a la compañía del pretendiente quien, ya rey de Castilla, lo nombró marqués de Villena. El acuerdo fue ratificado en marzo de 1366 y entonces se añadió el compromiso de que Leonor, hija del monarca aragonés, contrajese matrimonio con el citado hijo de Enrique de Trastámara, quien, muy poco después de la muerte de Pedro I en Montiel, el 23 de marzo de 1369, se convirtió en Enrique II de Castilla y se aprestó a defender los intereses de su reino y se negó a entregar los territorios que había prometido al rey aragonés quien envió a Lope Fernández de Luna, arzobispo de Zaragoza, a Castilla para que exigiese al nuevo rey castellano que cumpliese lo pactado y, además que entregase 200.000 florines como compensación por la ayuda que le prestó durante la guerra contra Pedro I. Pero Enrique II mantuvo su posición y nada se hizo entonces respecto a los territorios, ni tampoco se haría después, pese a los intentos y el empeño del rey aragonés, aunque la boda si se celebró en mayo de 1375, en la iglesia del soriano convento de San Francisco. El mes anterior, el día 12, se había firmado la Paz de Almazán que restableció la armonía entre Castilla y Aragón, y Pedro IV renunciaba a todas sus pretensiones territoriales, salvo a Requena y Molina sobre cuyo destino se entablarían conversaciones y, a cambio de la ayuda recibida Enrique II le entregaría 200.000 florines de oro que serían la dote de su hija Leonor cuando contrajese matrimonio con el heredero de Castilla. A mediados del siglo XV volvería a plantearse la cuestión y Alfonso V tuvo esperanzas de incorporar las tierras murcianas y, en septiembre de 1448, escribió al baile general de Valencia, Berenguer Mercader, para darle instrucciones sobre los preparativos militares para ocupar la ciudad de Murcia, que se había ofrecido para incorporarse a Aragón, y por ello el rey en la carta al baile hablaba de las fuerzas que sería necesario enviar, la financiación por espacio de seis meses y la finalización de las obras del alcázar de la ciudad. Vid. Cabezuelo Pliego 2004, p. 194; García Isaac 2015; Valdeón Baruque 1996, pp. 31 y 99-153; 1989, pp. 53-55. 
Cartagena a Castilla y cerró toda posibilidad de que Aragón tuviese frontera marítima con los nazaríes y Jaime II crease un eje mediterráneo Barcelona-Cartagena, de gran importancia estratégica y comercial ${ }^{4}$. Desde entonces el bajo Segura quedó como frontera entre los reinos aragonés y castellano, el cual perdía importantes núcleos como Orihuela, Elche, Alicante, Elda y Novelda que se integraron en la gobernación que se crearía años después y que tomaría el nombre de la primera de las citadas localidades ${ }^{5}$.

\section{LOS PRIMEROS PROBLEMAS}

La realidad impuesta en 1304, planteaba una situación hasta entonces desconocida e inquietante para quienes viviesen en Murcia o en Orihuela y tuviesen sus tierras, negocios o intereses del tipo que fuesen en el territorio asignado a Aragón o que había quedado en Castilla. No hay duda de que desde entonces las relaciones entre los habitantes de uno y otro territorio se hicieron muy difíciles ${ }^{6} \mathrm{y}$ en muchas ocasiones hostiles, pese a que hubo episodios de cierta distensión como, por ejemplo, con el Tratado de Tarazona, firmado el 6 de febrero de 1329 por Alfonso IV y Alfonso XI contra Granada, que dio lugar a todo un conjunto de negociaciones entre ambos reyes y los dirigentes murcianos y oriolanos, aunque las reticencias de Murcia eran muchas, ya que el pacto permitía la presencia de un ejército aragonés en la ciudad, si bien de paso hacia Granada, y muchos temían que una vez aquí se cambiasen las tornas y se repitiese lo acaecido hacía veinticinco años, lo que motivó la decidida intervención del rey castellano imponiendo el acuerdo y obligando a su cumplimiento ${ }^{7}$.

4. Torres Fontes 1990, p. 486; 1951, pp. 439-455. También Cabezuelo Pliego 2010; Cabezuelo Pliego, Barrio Barrio 2005; Ferrer i Mallol 2005, pp. 109-123.

5. La Gobernación de Orihuela fue creada en 1366. Vid. Cabezuelo Pliego 1988-1989, pág. 163.

6. Sobre la conflictividad fronteriza desde Torrellas, Ortuño Molina 2011, pp. 82-86.

7. Alfonso XI notificó a todos sus reinos el acuerdo y ordenó al adelantado y concejo se Murcia que lo cumpliesen, prestasen pleito-homenaje a Alfonso IV y que recibiesen el que habían de prestar en Aragón, para lo cual designó a Pedro López de Ayala, adelantado de Murcia, y a Ruy Sánchez de Aynar, 1329-II-6, Tarazona, 1329-IV-11, Alcalá de San Yuste y 1329-IV-14, Madrid, ed. Veas Arteseros, 1997, Doc. CXIX, CXXVI, CXXVIII, CXXIX. El monarca aragonés envió con plenos poderes al reino de Murcia a Jofré Gilabert de Cruilles, procurador de Orihuela, quien llegó a Murcia y debió encontrar resistencia en los regidores y oficiales murcianos que elevaron consultas a Alfonso XI quien les ordenó taxativamente que "reçibades et fagades acoger luego sin detenimiento ninguno y, en la dicha çibdat de Murçia, al dicho rey de Aragon et a todas sus gentes et que fagades uos, el conçejo de Murçia, jura, pleito et homenaje al dicho rey de Aragon o al su çierto procurador que el alla enbiare..., en la manera que se sigue, conuiene a saber: Que uos, el dicho conçejo de la dicha çibdat de Murçia, nin los moradores dende non ayades nin podades auer nin poner, en general nin en espeçial, paz nin tregua con el rey de Granada nin sus gentes, nin su tierra nin con alguno dellos. Et, otrosy, que acogades et reçibades al dicho rey de Aragon et a los infantes ... et a los sus ricos omes et a sus gentes, con el dicho rey de Aragon o sin el, cada que vernan a la dicha çibdat por fazer guerra contra los dichos moros, et que defendades et guardedes al dicho rey de Aragon et a las sus gentes et les ayudedes a fazer la dicha guerra et les daredes viandas por sus dineros", 1329-IV-11, Alcalá de San Yuste, Ibid. Doc. CXXVII. La carta de Alfonso IV nombrando su representante a Jofré Gilabert y la del consell de Orihuela designando 
Entre los habitantes de Murcia que sufrieron en primera persona los efectos de Torrellas, existía una importante animadversión tanto hacia los aragoneses en general como, sobre todo, respecto a los murcianos que de alguna manera habían colaborado en la ocupación y que en la mente de aquéllos eran los culpables de la amputación territorial, los cuales quedaron señalados y desamparados tras la marcha de las fuerzas aragonesas, lo que provocó una emigración a tierras oriolanas de los más significados y otra inversa hacia Murcia de los disconformes con el acuerdo ${ }^{8}$. En todo caso existía un clima proclive a la revancha y venganza en cuanto se presentase la oportunidad 9 .

procuradores para que firmasen los acuerdos a Guillén de Limiñana, Guirau de Clariana, Alfonso Rosell, Lope Garcia de Ayala, Pere (Ortiz?), Berenguer de Berga, Pere Salvanyes, Juan Masquefa, Berenguer de Val Flor, Guerau Vidal, Jacme Masquefa, Dominguello Morells y Bertrand LLeopard, 1329II-6, Tarazona y 1329-III-30, Orihuela, ed. Veas Arteseros, Molina Molina 2015, Doc. XLII y XLIII. Pero Alfonso IV tenía dudas de la actitud de los murcianos porque, aún en Tarazona, el 7 de febrero, escribió a Alfonso XI para decirle que había declarado la guerra a Granada y pedirle que mandase que los de Lorca y Murcia le prestasen homenaje en manos del citado Jofré Gilabert de Cruilles, 1329-II-7, Tarazona, Moxó y Montoliu 1982, p. 178. Sobre estas cuestiones, Cabezuelo Pliego 1999, pp. 166-167; Sánchez Martínez 1981, 1993; Torres Fontes 1986-1987.

8. La ocupación aragonesa generó apoyos y oposiciones por todas partes que provocaron, por ejemplo, escisiones en las encomiendas de la Orden de Santiago, unas que se sometieron a Jaime II sin problema y otras más reticentes, y lo mismo sucedió en las poblaciones, de manera que muchos tenían motivos para pensar que tras la marcha de las fuerzas aragonesas, podría venir un ajuste de cuentas respecto a los que colaboraron con las fuerzas de ocupación y sus dirigentes, aunque en la mayoría de los casos la aceptación del dominio de Jaime II fue consecuencia del desgobierno en Castilla y del convencimiento que tuvieron los hombres de estas tierras de que socorro alguno se podía esperar y que era inútil ofrecer una resistencia armada cuyas posibilidades de éxito eran nulas o muy escasas. Sólo en Mula lograron los vecinos desalojar a los aragoneses. Jiménez Alcázar 2008; Sainz de la Maza Lasoli 1996-1997. Sobre la ocupación aragonesa del reino de Murcia, entre otras, se pueden consultar: Estal Gutiérrez 1982, 1984, 1985-1990; 1990-1991, 1996-1997, 1998; Ferrer i Mallol 1990; Molina Molina 1996-1997.

9. Durante el siglo XIV las relaciones entre Castilla y Aragón fueron pacíficas pero difíciles, pues para un sector de la sociedad castellana Torrellas era una derrota que generaba un permanente deseo de desquite, como señala Ferrer i Mallol al indicar que Juan Manuel, en 1325, dijo a Jaime II que "Alfons XI tenia pensat, tan bon punt es fes càrrec del govern de Castella, en assolir la majoria d'edad aquell any, atacar el monarca català fins que li haguès retut tot el que tenia del regne de Múrcia”, pero las buenas relaciones entre el rey castellano y Alfonso IV alejaron la guerra. Sin embargo, la muerte de Alfonso XI y la entronización de Pedro I quien no ocultaba "el seu desig d'obtenir la revenja de la guerra catalano-castellana del 1296 i de desfer els efectes de la pau de Torrellas" materializó la guerra entre cuyas principales causas estaba el deseo castellano de recuperar el territorio murciano perdido. Lo mismo se puede decir de la existencia de un resentimiento en la sociedad murciana que padeció la pérdida de una importante porción de su espacio que convirtió a antiguos vecinos en rivales y, en ocasiones, en enemigos, lo que explica la petición que el concejo murciano hizo al rey para que las localidades que había incorporado en la guerra devolviesen a los murcianos afectados las propiedades que poseían en ellas y que les fueron confiscadas, con lo que se reforzaría el regreso de las mismas al reino de Murcia, a lo que accedió Pedro I que escribió a las autoridades de "Alicante e de Elche e de Guardamar e todos los otros lugares que son en el regno de Murçia, que yo gane del rey de Aragon ... Sepades que el conçejo e ofiçiales de la çibdat de Murçia me enbiaron dezir que antes de esta guerra que yo he con el rey de Aragon se començase, que algunos de sus vezinos que auian en esos lugares o en algunos dellos e en sus terminos heredades e otros bienes rayzes, e que despues que se començo la dicha guerra que....dieron los dichos bienes a algunas personas; e enbiaron me pedir merçed que, pues esos dichos lugares son míos, mandase tornarles los dichos sus bienes ... Porque vos mando ... que dedes, e tornedes, e fagades desenbargar a los de la dicha çibdat de Murçia todas las heredades e bienes 
La situación planteada tras Torrellas favorecía los altercados y Fernando IV quiso aquietar los ánimos perdonando a los vecinos de Lorca, Murcia, Alhama y Molina Seca:

\begin{abstract}
de todas las cosas que fizieron et dixieron fasta el dia que esta carta es fecha... Et aseguroles que non les faga mal nin daño en sus personas nin en sus bienes, et, si por auentura, quisieren morar en las villas et en los dichos logares que moren y et se aprouechen de todo lo suyo bien et conplidamente ${ }^{10}$.
\end{abstract}

El rey pretendía cerrar una etapa y abrir otra que enlazaba con 1296, antes de la ocupación aragonesa que quedaba para el olvido, aunque para muchos no fuera así, tal y como lo ponen de manifiesto las reivindicaciones de personas e instituciones para que les fuesen devueltas las propiedades que habían tenido bajo soberanía aragonesa y que habían perdido ahora e incluso mucho tiempo antes ${ }^{11} \mathrm{o}$ las peticiones de los parientes de Ramón Eymerich presentadas a los alcaldes de Murcia para que ejecutasen una sentencia condenatoria pronunciada contra Berenguer, Bernat y Guillén Fortuyn, culpables de la muerte de Aymerich que bien a treynta et tres años que ... fue muerto en Muruiedro, es decir en 1305 se reclamaba por un suceso acaecido en 1272. Los alcaldes ante esta petición contra tres de sus vecinos más antiguos, pues son moradores de Murçia bien a treynta et siete años o mas, consultaron al rey y paralizaron toda acción hasta que se pronunciase sobre el asunto ${ }^{12}$.

rayzes que ellos o alguno dellos auian y en los dichos lugares e en sus terminos antes que se començase la dicha guerra como dicho es...”. Ferrer i Mallol 1987, pp. 445 y 452; Gutiérrez de Velasco 1951, p. 217. La carta de Pedro I, 1364-VI-21, Moya, ed. Molina Molina 1978. Doc. 99.

10. 1304-VIII-10, Agreda, ed. Torres Fontes 1980. Doc. XXVI. Además el rey les concedía facultad para poder vender, arrendar o cambiar todos sus bienes en el caso de los que se quisieren marchar a otras partes, salvo que no pudiesen venderlos a miembros de las ordenes militares, eclesiásticos o personas "fuera del mio señorio". Pero el perdón real no borraba recuerdos de humillaciones pasadas ni minoraba deseos de venganza y en la corte sabían que "por razon de algunas muertes et otros fechos de justiçia que se fizieron y ante del dicho perdon, que algunos que mueuen demandas contra otros", por lo cual el rey confirmó el perdón y desde Guadalajara, el 12 de febrero de 1305, ordenó al adelantado Juan Ozores, a los alcaldes y alguaciles de las citadas poblaciones que no consintiesen bajo ningún concepto mover pleito alguno relacionado con tales sucesos anteriores al perdón. Ibid. Doc. XXXVI.

11. En este contexto se inserta el rechazo de Fernando IV a las pretensiones del prior y convento de Cornellá, que demandaban "vna quantia de heredamientos que Porçel Porçel et otros omes de Murçia que y son tienen por derecho", porque alegaban los clérigos que ellos los poseían antes de la rebelión mudéjar de 1264. Fernando IV argumentó que "si estas demandas se fiziesen, que seria grand daño e despoblamiento de la uilla de Murçia, et que muchos otros estan catando por fazer semejantes demandas destas si esto pasase", y determinó que de ningún modo se admitiesen reclamaciones sobre heredamientos poseídos antes de los repartimientos ordenados por Alfonso X tras 1266, por lo cual nadie podía "fazer demanda nin quistion ninguna, nin sean oydos sobrello en ninguna manera, mas aquellos que fincaron tenedores de los heredamientos al tienpo de la partiçion, que les finquen saluos et seguros et sin contienda a ellos o a aquellos que los ouieron dellos de entonçe aca". 1305-II-12, Guadalajara. Ibid. Doc. XXXI.

12. Berenguer Fortuyn, Bernat Fortuyn y Guillén Fortuyn fueron condenados en rebeldía, posiblemente en Valencia, porque por entonces estaban en Murcia en servicio de Alfonso XI y, tal vez, siendo culpables, decidieron quedarse en Murcia resguardados de lo que les podría pasar si cruzasen la frontera con Aragón. Los parientes del difunto debieron seguir investigando sobre su paradero y tras 
Torrellas también trajo problemas en el orden eclesiástico, porque el mantenimiento de la jurisdicción del obispado de Cartagena en el lado aragonés de la frontera era un contrasentido que causaría importantes quebraderos de cabeza al titular de la sede, quien obraba con energía para mantener unida la diócesis y no perder los ingresos procedentes de la zona aragonesa y a la vez mostraba una actitud conciliatoria, algo muy difícil de lograr, porque aunque el prelado trabajase en compaginar los intereses de la Iglesia y los de sus fieles aragoneses, el objetivo de éstos de lograr la identificación política con la religiosa, hacían inviable la concordia. Finalmente, el fracaso de los esfuerzos de Jaime II para que Juan XXII autorizara la erección de un obispado con sede en Játiva y que abarcara los territorios incorporados ${ }^{13}$, así como de las peticiones enviadas por sus sucesores a la Santa Sede, provocaron el mantenimiento de la situación y que los habitantes de la procuración oriolana, súbditos de Aragón, siguieran como fieles de la sede cartaginense y por ello los problemas serían continuos, sobre todo a la hora de pagar las cantidades debidas al obispo y cabildo ${ }^{14}$.

localizarlos en Murcia acudieron ante los alcaldes para que ejecutasen la sentencia en los tres y en sus bienes, lo cual, según expusieron los emisarios murcianos a Fernando IV, era contrario al perdón que había dado "en que les perdone todo quanto fizieron et dixieron fasta aquel dia et mande que por razon de muertes et de otros fechos de justiçia que fuesen fechos antes del perdon, que tenia por bien que ningunos ouiesen demanda contra ellos". El rey asumió esa posición y los tres encausados quedaron amparados por la merced real que, como vecinos de Murcia, les debía ser guardada y así ahora lo mandaba al adelantado Diego Garcia. A los parientes de Ramón Eymerich les quedaba la posibilidad de demandarlos "por su fuero", es decir, en Aragón, pero el resultado sería el mismo, pues no cabe pensar que ninguno de los encausados compareciese, ya que sería inmediatamente detenido, ni la extradición, mal regulada por entonces, surtiría efecto pasados tantos años desde la comisión del delito. 1305-IX28, Burgos. Ibid. Doc. LVIII. Vid. López-Amo Marín 1956.

13. 1317-XI-23. Torres Fontes 1953, p. 397. No tuvo éxito el rey aragonés ni tampoco sus sucesores lo alcanzaron aunque cambiaran el centro de la sede a Orihuela. Finalmente, el proyecto acabaría por materializarse en el siglo XVI con la creación de la diócesis oriolana. Vid. Carrasco Rodríguez 2001, pp.14-60; 1996-1997.

14. Los vecinos de Orihuela y de otras localidades se escudaban en el anacronismo que significaba ser al mismo tiempo súbditos del rey de Aragón y fieles del obispado de Cartagena para no pagar ni censos ni diezmos ni primicias a una institución que no era de su reino sino del de Castilla. Ante esa actitud los prelados utilizaran la excomunión y el entredicho para obligar a los que no querían cumplir sus obligaciones como fieles, aunque estas medidas espirituales no siempre surtían el efecto deseado y lo único que hacían era incrementar la animadversión hacia la Iglesia de Cartagena, tanto por el asunto del pago de los diezmos como por las exigencias impositivas que los clérigos debían satisfacer y que no pagaban en la demarcación oriolana. Sobre estas cuestiones, Torres Fontes 1956, pp. 483-502; Veas Arteseros 2002, pp. 993-1014. Los oriolanos no se consideraban afectados por las disposiciones reales que en Castilla obligaban a los habitantes a pagar los diezmos y otras rentas a la Iglesia, buscando no pagar a nadie, ya que no estaban adscritos a diócesis aragonesa alguna. Con anterioridad a Torrellas, las resistencia a pagar el diezmo en las localidades que formarán parte de la Gobernación de Orihuela era una realidad, reconocida por Sancho IV, quien indicó a Juan Sánchez de Ayala, lugarteniente de adelantado por Juan Manuel, como en el pleito que sostenían el obispo y cabildo, por un lado, y los concejos de Murcia, Orihuela y "de todos los otros logares de su obispado", por otro, a causa del pago del diezmo, él había ordenado que en Murcia se abonase como en Sevilla, y en las restantes localidades del obispado de Cartagena tal y como se pagaba en las poblaciones del arzobispado hispalense. "Et agora el obispo et el cabildo enbiaronseme a querellar que ay algunos del obispado, asi como de Orihuela e de Guardamar e de otros logares, que non quieren dar diezmo asi como se contiene en el quaderno que tiene el obispo, sellado con los sellos del cabildo e del vicario de Sevilla e lo yo libre por mis cartas". 


\section{EL APROVECHAMIENTO DEL AGUA Y RECURSOS NATURALES}

El agua, por su escasez o exceso, ha marcado siempre las tierras surestinas, proporcionando una continuidad geoeconómica, que Torrellas también rompió, al convertir el río Segura en un cauce internacional y desde entonces las cuestiones que se planteaban sobre el uso y disfrute del agua ${ }^{15}$, que antes se solucionaban entre vecinos, todos habitantes del reino de Murcia, lo que proporcionaba una identidad y facilitaba el acuerdo, después se convertía en una rivalidad que hasta aquellos momentos no existía, al menos con esos agrios matices. Es verdad que las disputas entre Murcia y Orihuela por el aprovechamiento de los caudales no eran nuevas, pero desde Torrellas se agravan y el empleo de la fuerza se generalizará desde el momento en el que el consell, obligado por las necesidades de riego, realizó obras que represaban el agua y provocaban una ralentización de su velocidad de paso, con lo cual las norias se paraban y los riegos sufrían perjuicio en la parte de Murcia. Entonces lo más usual era que el concejo cuyos vecinos eran perjudicados por las construcciones enviase efectivos para destruirlas y restablecer la normalidad, aunque esas acciones provocasen la reacción violenta del otro lado.

Así sucedió en 1318, porque los oriolanos construyeron una presa que fue fecha de nueuo en el rio de Segura, en termino de Orihuela, çerca Beniaçan, ateniente del termino de Murçia, para regar las heredades de Moquita e de Beniaçan, terminos de Orihuela en perjuicio de los herederos de Beniafel, de Rafal e de Alfandari, terminos de Murçia, que dizen que reçibian danyo en sus heredades e en sus anyoras, que tienen de antigo fechas, al no poder regar sus huertas como solían, lo que hizo que desde Murcia se enviasen fuerzas para destruir la presa que volvía a ser reconstruida por los oriolanos en una serie de acciones-reacciones totalmente inútiles, a las que había que sumar las reparaciones por los danyos reçibidos por el la vna parte e por el otra por este fecho. Las negociaciones para solucionar el problema fracasaban porque desde uno y otro lado se defendían intereses contrapuestos y, finalmente, Murcia y Orihuela acordaron someter sus diferencias al arbitraje de una comisión que, presidida por don Juan Muñoz Gómez de Hinojosa, obispo de Cartagena, tenía de plazo desde el 6 de julio hasta el 31 de agosto para dar una resolución que todas las partes se obligaban a cumplir ${ }^{16}$.

Tal incumplimiento tenía que ser castigado por el adelantado con el embargo de bienes de los contraventores hasta que pagasen. 1290-VII-21, Valladolid. Tampoco querían pagar el diezmo los alcaides y los almojarifes de Elda y Novelda. 1292-V-3, Ciudad Rodrigo. Gaibrois de Ballesteros 1928. Doc. 314 y 421; Torres Fontes 1977. Doc. CIII. Si los de Murcia u otras localidades del reino no pagaban el adelantado podía embargar sus bienes, pero no tenía jurisdicción en Orihuela y no hay que pensar que las autoridades oriolanas ni de la gobernación pusiesen mucho empeño en obligar a sus vecinos a pagar.

15. Sobre el agua y lo que representaba en Murcia, es obligado consultar las obras de Martínez Martínez 2010a; 2010b, pp. 64-74; 2011-2012.

16. La comisión estaba integrada por Bernat de Claramunt, Pedro Guirao y Berenguer Çatorre, por la parte de Murcia, y Juan Carles, Domingo Ponzano y Francesc Masquefa, por la de Orihuela. 1320-VII-6, Murcia. AMM, Pg., N. 95. Ed. Veas Arteseros, Molina Molina 2015. Doc. XVIII. Bellot nos dice que la comisión se reunió dos veces en Beniel y, además de los citados, acudieron el procurador general, justicia, jurados y prohombres del consell y el adelantado Pedro López de Ayala y muchos 
También había problemas a causa de la pesca de anguilas que practicaban subrepticiamente vecinos de Orihuela dentro del término de Murcia, en los despoblados y amplios almarjales de Monteagudo ${ }^{17}$, muy próximos a la frontera oriolana. La solución que halló el concejo para evitar tales hechos y a la vez poblar esas zonas fue el reparto de tierras tanto en la parte pantanosa de Monteagudo que, previa desecación, sería puesta en cultivo, como en todas las tierras del término lindantes con el oriolano que habían sido abandonadas por sus antiguos dueños, emigrados o muertos sin herederos, contando con el apoyo de Fernando IV quien reconocía que que si tales heredamientos fuesen dados et partidos a vos, que seria mio servicio et pro et poblamiento del lugar ${ }^{18}$.

En todo caso el cauce del Segura que unía ambas partes de la divisoria murciano-oriolana, siguió siendo marco de encuentros y desencuentros a lo largo de la Baja Edad Media, y los de Murcia sufrirán primero las consecuencias de la riadas que aguas abajo llegaban a Orihuela, a donde no sólo aportaban agua y animales muertos además de mucho ramaje, sino que en ocasiones proporcionaban elementos aprovechables como madera, en torno a la cual también habrá pleitos al quedarse los oriolanos con ella en perjuicio de sus dueños, pero no eran los únicos, pues también lo hacían los vecinos de lugares del alfoz murciano próximos al cauce, como El Raal, Alquerías y otros ${ }^{19}$.

regidores de Murcia, gastando en cada una de ellas "80 gallinas, 6 carneros, 20 cabritos, etc.”. Bellot 2001, 2, p. 203; García Samper 2007, p. 405.

17. La pesca de las anguilas iba pareja al arrendamiento del azarbe de Monteagudo por el concejo de Murcia y planteó problemas porque los arrendadores que pescaban las anguilas, alegando que pagaban un dinero por el impuesto de la sisa y libras, no siendo verdad, vendían la libra más cara de lo ordenado por el concejo, lo que provocó quejas ciudadanas y que el tema se tratase en la sesión concejil del 14 de julio de 1397: "Otrosy, por quanto en el dicho conçejo fue dicho que algunos omes, vezinos de la dicha çibdad, que tenian arrendado la açarbe de Montagudo, que venden las anguilas a seys dineros la libra e que pescaban en el dicho açarbe, diziendo que pagaban vn dinero por libra y sisa. E por quanto fue fecha relaçion por algunos arrendadores de los comunes a acreçimiento del dicho conçejo de la dicha çibdad que los dichos pescadores de las dichas anguilas no pagaban cosa alguna de libras e sisa de las dichas anguilas, por esta razon el dicho conçejo..., hordenaron e mandaron que los tales pescadores que las dichas anguilas pescaren, que vendan la libra de las dichas anguilas de aqui adelante a çinco dineros e no mas, e que no paguen libras ni çisa alguna". AMM, AC 1396-1397, f. 21rv. El arrendamiento del azarbe y del propio almarjal de Monteagudo y la pesca de anguila era también cotidiano en el siglo XVI. Vid. Lemeunier 1997, p. 33.

18. 1308-VI-5, Burgos, ed. Torres Fontes 1980. Doc. LXXX. Un año después confirmaba la partición efectuada por el concejo, 1309-VIII-27, Sitio de Algeciras, Ibid. Doc. LXXXIX. Pocos datos tenemos de la repoblación en estos años, y uno de ellos se refiere al caso de Juan de la Peraleja, a quien el rey le concedió 1.000 tahúllas “en el Almarjar", tal vez el de Monteagudo, con un censo anual de 32 maravedís. Ibid. Doc. LXXIX.

19. Hechos de este tipo se sucedieron con relativa frecuencia, como ocurrió durante una riada en septiembre de 1399: "E por quanto agora pocos dias ha fue trayda madera de pino por el rio de Segura por (en blanco) para prouisyon de la dicha çibdat e trayendola por el dicho rio, por la creçida de aquella, la dicha madera se desbarato e se fue della a Orihuela e della se quedo en Raal e en las Çinco Alquerias e en otros lugares de la huerta, la qual tenian omes çiertos de la dicha çibdat sacada del rio e que la no querian dar al dicho (en blanco) diziendo que eran de aquellos que la sacauan. Por esta razon el dicho conçeio...., por quanto dixieron que la dicha madera era trayda para prouision e mantenimiento de la dicha çibdat e por ge la desbaratar e leuar el dicho rio contra su voluntad del dicho (en blanco) ... ordenaron e mandaron que la dicha madera sea tornada al dicho (en blanco), que sea dado a los que 
También había otras cuestiones frecuentes que ocasionaban problemas, como lo eran los causados por la entrada de gentes en el término ajeno para realizar actividades económicas puntuales, como caza de conejos, perdices e incluso jabalíes en las zonas de sierra y monte bajo comarcanos de uno y otro lado $^{20}$, corte de madera, elaboración de carbón vegetal, recolección de esparto, junquillo y grana, asi como otros trabajos relacionados con el aprovechamiento de los recursos naturales. La mayoría de las veces el destino de tales productos era la venta en el mercado local, como sucedía sobre todo con la grana, que se comenzaba a recolectar en primavera, aunque su máxima explotación se realizaba durante el mes de mayo ${ }^{21}$, y que constituía un ingreso, complementario o no, de muchas familias.

la sacaron por su afan e trabajo vn maravedi por cada madero, et que asy sea vsado e se vse de aqui adelante en otra qualquier madera que a la dicha çibdat fuere trayda". AMM, AC 1398-1399, sesión del 14-IX-1398, f.. 64.

20. La cotidianeidad de estas actividades cinegéticas, ya fuese para consumo propio o para vender en el mercado, muchas veces implicaba adentrarse mucho en el término vecino e incluso penetrar en las dehesas concejiles cuyo uso era exclusivo de los vecinos del lugar en cuestión, y no eran raros los casos en que los caballeros de la sierra se incautaban de los perros, aperos de caza y de las piezas capturadas a muchos individuos, algunos de los cuales eran conocidos y que tras ser prendados, ellos o algunos de sus hombres, acudían ante las autoridades para que les devolviesen lo tomado, lo cual ocasionaba impunidad de unos mientras que otros no recibían el mismo trato, pues el concejo, con escasa base, propiciaba el incumplimiento de sus propias ordenanzas en función de la categoría de los infractores o de lo que ofreciesen a cambio, que también podía ser. La situación, además de recurrente, alcazaba grandes proporciones, por lo cual el concejo ordenó que cuando un regidor pidiese a algún caballero de la sierra que devolviese lo tomado a algún vecino de Orihuela que había sido sorprendido cazando en el termino de Murcia, estuviese obligado a pagar de sus bienes el valor de lo apresado. Así se dijo en la sesión concejil del 8 de diciembre de 1405: "los vezinos de la villa de Orihuela que entran grant tierra en el termino de Murçia a caçar, asy perdizes como conejos e avn puercos jaualines, por lo qual era muy bien de poner çiertos omes buenos por caualleros de la sierra para que guarden el termino de la dicha çibdat, porque los dichos vezinos de Orihuela ni otros algunos, naturales de la tierra e señorio del rey de Aragon, no entren a caçar al dicho termino de Murçia ni en la dehesa della. Et que los que fueren puestos por caualleros de la sierra que lo guarden bien e verdaderamente, et todo lo que con derecho fuere tomado por los dichos caualleros que sea suyo, como el dicho conçejo.... prometen e prometieron que no rogaran ni faran rogar a los dichos caualleros que lo tornen, et sy lo fizieren quel regidor o regidores que les rogaren o fizieren rogar lo que asy con derecho fuere por ellos tomado, que ge lo paguen de lo suyo al dicho cauallero o caualleros de la sierra, tanto quanto fuere lo que asy sera tomado". AMM, AC 1405-1406, AC 27, sesión del 1405-XII-9, f. 78v.

21. El tema de la grana era tratado con frecuencia en las reuniones concejiles, por ejemplo, la del 22 de abril de 1393, año en el que la grana fue muy abundante y por ello se preveía la llegada masiva de oriolanos, y en el concejo se dijo que: "Otrosy, por quanto en este año en que somos en el termino desta dicha çibdat ay mucha grana e es fama que los de Orihuela quieren entrar a coger la dicha grana en nuestro termino, ordenaron que Bartolome Tallante e Lazaro Sánchez de Leon....vayan por mensajeros al conçejo de la villa de Orihuela en razon de la dicha grana”. El objetivo de los representantes murcianos de convencer a los miembros de consell de que disuadiesen a sus vecinos del empeño en recolectar grana estaba condenado al fracaso, pues estaban en su derecho siempre que fuese en el propio término, pero uno de los grandes problemas de Torrellas era la imprecisión de la frontera entre Murcia y Orihuela, por lo que era muy fácil invadir el alfoz vecino y provocar la reacción de las autoridades, cuando no la de sus propios vecinos que podía ser más violenta y de más graves repercusiones, por lo cual se adoptaron medidas porque "mucha conpaña de la dicha çibdat van a coger la grana que es en termino de Murcia, e eso mesmo van mucha conpaña de Orihuela a coger la dicha grana entre su termino, la qual grana se a de ronper el jueues, primero que viene, que es primero dia de mayo, e por quanto los mojones de los terminos de Murçia e de Orihuela no son bien declarados et puede ser que 
Ante tales acciones los dirigentes municipales defendían su jurisdicción frente a los intrusos, ya se tratase de convecinos del mismo reino ${ }^{22}$, y mucho más si eran gentes procedentes del otro lado de la frontera las que penetraban en las tierras meridionales del reino de Valencia para realizar las mismas actividades que los de Orihuela llevaban a cabo en el término de Murcia, a veces ocultando un tráfico ilícito, sobre todo de cereales y ganados ${ }^{23}$.

entre los vezinos de Murçia e de Orihuela recreçiera contienda o pelea sobre el coger de la dicha grana. Et por escusar contienda e daño de entre los de la vna parte e de la otra rogaron al noble don Ramon de Rocafull, vasallo del rey nuestro señor, vezino de la dicha çibdad, que presente era, que en vno con Johan Sanchez de Ayala el moço e Alfonso de Vallibrera e Diego Tomas e Françisco Ferrandez de Toledo e Juan Vylatorta e Lope Canpanadal e Juan Moraton e Bernat Forniles, Ponçe Saurin e Anton de Roda ... que vayan ... a las contiendas de los terminos e pongan paz e sosiego entre los vnos de la vna parte e de la otra". AMM, AC 1392-93, AC 16, sesiones del 22-IV-1393 y 29-IV-1393, ff. 281v y 298r-v. La recolección de grana en estas zonas viene, como tantas otras cosas, de época andalusí, Vid. García Sánchez 2001, p. 447; Partearroyo Lacaba 2005, p. 43; Rodríguez Peinado 2012, pp. 267 y 272.

22. Asi sucedió con Aspe, a cuyo término acudían habitualmente desde mucho tiempo atrás vecinos de Orihuela a recoger grana, concentrándose unas 300 personas tanto para este menester, como para coger madera, hacer carbón vegetal y cazar conejos y perdices, al parecer sin ser molestados, por eso su sorpresa cuando en 1434 se les prohibió y comenzaron los embargos y represalias que dieron lugar a un pleito entre ambas localidades. 1434-VI-26. Y lo mismo sucedía en otras localidades, como los contenciosos sobre la grana mantenidos por Villena y Onteniente, 1459-V-10, Barrio Barrio 2008, pp. 8-10.

23. Se trata de cuestiones atemporales y que comenzaron antes de que se estableciera la frontera pues vecinos de Orihuela entraban en término murciano y viceversa persiguiendo la caza o recolectando grana, pero, como he dicho, ahora la pertenencia a estados distintos daba una dimensión diferente y si antes se toleraba generalmente, después de Torrellas no. La recolección de hierbas, grana, tala de árboles para madera, recogida de leña verde, elaboración de carbón vegetal, caza, etc., fueron tipificadas por el consell oriolano en diferentes etapas, lo que indica el incumplimiento sistemático de las prohibiciones por parte de los murcianos, lo mismo que sucedía a la inversa con los procedentes de la zona oriolana. En Orihuela se prohibió que quienes no fueran vecinos de la localidad realizasen las citadas actividades, so pena de perder los bienes recolectados, los perros, hurones y artes de caza, además de las piezas cobradas y, claro está, de la multa pecuniaria que en su caso fuese establecida. En Orihuela existían caballeros de la sierra como en Murcia, muestra de la identidad entre ambas localidades que Torrellas no pudo borrar, mientras que en otras poblaciones como Villena, Elche y Onteniente se organizaban patrullas de guardas para vigilar el acceso a las zonas de recolección de grana e impedir su aprovechamiento por los vecinos de otros términos. Barrio Barrio 2008, pp. 11 y 14; Martínez Martínez 1995, p. 57. El tráfico fronterizo, fuera por las zonas de paso habituales o por aquellas poco vigiladas y frecuentadas, era un problema también porque favorecía la salida de cereales o de reses cuando las traían a pastar o a comerciar con ellas sin la presencia de los serviciadores y demás recaudadores de las rentas sobre el ganado o de los alcaldes de las sacas, pues no era raro que saliesen camino de Orihuela mas reses de las que habían entrado en el campo murciano. Estas y otras cuestiones en momentos de carestía, por ejemplo, de cereales aumentaban la tensión y fueron causa de que el concejo de Murcia endureciese su postura: "Por quanto al dicho conçejo fue dicho e dado a entender e avn ello es asy que muchas personas, vezinos e moradores de la tierra e señorio del rey de Aragon que labran e son labradores de heredades que son del señorio del rey de Castiella, nuestro señor, e que todo el pan que en ellas cogen que se lo lleuan e pasan al dicho señorio de Aragon, seyendo defendido por el rey, nuestro señor. Et, otrosi, que los de la tierra e señorio del rey de Aragon, asi de cauallo como de pie, que entran en lo de Castiella e en termino desta dicha çibdat a caçar puercos e conejos e perdizes e a cortar madera e a coger grana e a fazer carbon e avn a paçer sus bueyes e yeguas e bestias e sus ganados. E por esto acaesçen entre los del señorio del rey, nuestro señor, e del señorio del rey de Aragon grandes contiendas e avn muertes de omes". Todo ello justificaba las siguientes ordenanzas del concejo: 


\section{EL PROBLEMA DE LOS IMPUESTOS}

La frontera establecida en Torrellas también trajo novedades para el comercio de ambos lados a causa del establecimiento de impuestos desconocidos hasta entonces, en concreto las innovaciones tributarias realizadas en varios lugares de la procuración de Orihuela, como la veintena, impuesto que gravaba las transacciones comerciales, cuyos efectos sintieron los mercaderes Ferrán Pere, Antón Tecas y Pedro Guirao, vecinos de Molina Seca, quienes, en enero de 1354, comparecieron ante el concejo molinense para exponer que ellos yendo de cada dia $y$, al vuestro lugar por uender sus cuerdas e otras mercaderías, se encontraban con las exigencias de los almojarifes que recaudaban los derechos del infante don Fernando y les obligaban a pagar veintena y otros impuestos de las mercancías que vendían y compraban ${ }^{24}$. También los vecinos de Murcia tenían el mismo problema

"E otrosi, el dicho conçejo ... ordenaron que alguno ni algunos vezinos ni moradores de la dicha çibdat no sean osados de tomar a labrazon a quinto ni a medias, ni a renta ni en otra manera en la huerta e termino de la villa de Orihuela ni en el señorio del rey de Aragon, so pena de mil maravedis para la lauor de los adarbes de la çibdat, ni, otrosi, que ningun vezino ni morador de la tierra e señorio del rey de Aragon, que no sea osado de tomar labrazon alguna ni labre al quinto ni a medias ni en otra manera en la huerta e termino de la çibdat de Murçia, e sy lo fiziere que pierda lo que senbrare en la tal labrazon e que sea, otrosi, para lauor e reparamiento de los dichos adarbes.

Et otrosi, que ningund vezino de la tierra e señorio del rey de Aragon no sea osado de poner a paçer en el termino de Murçia bueyes ni vacas, ni bestias ni yeguas, ni otros qualesquier ganados de qualquier natura que sean, e si lo fizieren que pechen en pena, es a saber, el buey o vaca o yegua o otras bestias çinco maravedis por cada cabeça e el ganado vn maravedi por cada cabeça.

Otrosi, que ningund vezino e morador de la tierra e señorio del rey de Aragon, asi de cauallo como de 'pie, no sean osados de entrar en el termino de Murçia, es a saber, a caçar conejos ni perdizes, ni puercos ni a fazer carbon, ni a coger grana ni a tajar madera, e sy lo fizieren que pierdan los perros e los furones e la grana e que pechen en pena sesenta maravedis cada vno por cada vez de las que fueren fallados faziendo las cosas sobredichas.

Otrosi, el dicho conçejo e ofiçiales e omes buenos escogieron por mensajeros para que vayan a la villa de Orihuela con cartas e con estas ordenaçiones sobredichas Juan Sanchez de Ayala, fijo de Juan Sanchez de Ayala, e Juan Sanchez de Ayala, fijo de Pedro Lopez de Ayala...". AMM, AC 1398-1399, AC 22, sesión del 1399-IV-5, f. 174r-v.

24. El concejo de Molina expresaba su sorpresa por la novedad al consell, pues hasta ahora sus vecinos no pagaron "derecho alguno y en el dicho vuestro lugar de cosa alguna que alla vendiesen nin conprasen, ni, otrosi, en ningun tienpo fasta aqui vezinos uuestros no pagaron aqui derecho alguno por cosa que aqui vendiesen o conprasen. Et pues aqui los vuestros vezinos nunca fasta aqui pagaron, en ese lugar no esta en razon que los nuestros vezinos paguen ahi derecho alguno de lo que hi lieuan e venden". El consell respondió con evasivas alegando ignorancia del hecho: "tro açi nos no auem sabut de çert que algun vehi uostre peche ni aja pagat vintena de alguna cosa que açi aporte", pero las afirmaciones de los comerciantes molinenses no eran un invento y por ello terminó reconociendo la realidad y se comprometió "per conseruar la bona vehindat que sienpre es estada e es entre nos" que en adelante ningún comerciante de Molina no pagaría veintena ni otro derecho de las mercancías que llevaren a Orihuela, eso sí, mientras en Molina no se cobrase a los oriolanos impuesto alguno. El mantenimiento de la buena vecindad y reciprocidad entre ambas localidades volvió a ser defendida por el consell cuando la tensión con Murcia alcanzó cotas de ruptura y escribió al concejo molinense para indicarles que no tenían intención de hacer guerra contra las gentes del rey de Castilla, que lo acontecido con Murcia lo hicieron "per justes e rahonables rahons" y que con respecto a Molina querían "fer a uos bona vehindat demetre que uos aço mateix façats a nos". 1354-I-26, Molina, 1354-I-31, Orihuela y 1354-XII-5, Orihuela, ed. Veas Arteseros, Molina Molina 2015. Doc. XCIX, C y CVI. La veintena 
y uno de ellos, Ferrán Martínez de Santo Domingo, se quejó a los regidores porque él había comprado ganado ovino en Orihuela y le exigieron que pagase la veyntena de la quantia que por quanto auia conprado el dicho ganado y que al negarse tuvo que presentar un fiador por el monto que le pedían. Todo ello en clara vulneración de las franquicias que amparaban a los murcianos que gozaban de exenciones tributarias hasta ese momento generalmente respetadas en la gobernación oriolana, tal y como los dirigentes murcianos expusieron en sus cartas al consell en las que reivindicaban su mantenimiento y le negaban potestad para poder hacerlo, pretendiendo mantener una realidad del pasado, pues tales franquicias no eran válidas en el reino de Aragón y por ello se imponía un replanteamiento de las relaciones entre unos y otros concejos ${ }^{25}$.

Hasta 1304 los comerciantes oriolanos, ilicitanos y alicantinos, entre otros, acudían con sus productos a las ferias y mercados de las poblaciones vecinas sin mayores dificultades pues pertenecían al mismo espacio político, lo mismo que hacían murcianos, lorquinos, ciezanos, molinenses y demás en las localidades de la Vega Baja, pero después ese comercio vecinal cambió a otro de tipo fronterizo, si se quiere "internacional", y la frontera se convirtió escenario de conflictos a causa de los excesos y atropellos, no sólo por causas tributarias, contra mercaderes aragoneses en Castilla y contra castellanos en Aragón, que generaban constantes represalias y una casi permanente situación de tensión que no beneficiaba a nadie, porque éstas no siempre se ejercían contra mercaderes o personas que eran vecinos de la localidad en donde se produjo el abuso, sino que, en ausencia de éstos, la represalia se efectuaba contra otros que procediesen del otro reino y que nada

también se cobraba en Villena. Gonzalez Arce, J.D.: "De conjunto de rentas a impuesto aduanero. La transformación del almojarifazgo durante el siglo XIV en el reino de Murcia", en Anuario de Estudios Medievales, 42/2 (2012), p. 671. Bellot al referirse a esta cuestión señala que cuando el Procurador Juan Sánchez de Ayala prohibió la entrada de los murcianos en Orihuela, “escribió Molina que en las pesadumbres pasadas hicieron convocación o concierto con Orihuela, siendo procurador general don Francés Acart, de que sienpre que quisieren hacer guerra, se avisen los unos a los otros 20 dias antes, con auto recibido por Guillén Serrá, notario de Orihuela, y asi les rogaban que les placiese avisar si quisieren hacer mal a Murcia”. Bellot 2001, 2, pp. 245 y 294,

25. Murcia decía: "somos de uos marauillados en demandar veyntena a ningun nuestro vezino por cosas que hi conpre o venda, ca sabedes bien que nunca en ningun tienpo nuestros vezinos ni avn otros algunos no pagaron veyntena en el dicho lugar de Orihuela, ni auedes preuillegio ni carta alguna por do lo podiesedes cojer ni tomar, mayormente que es çierto e notorio a uos e avn a todos los del senyorio del rey de Aragon, que no ay otra aduana ni almoxarifadgo syno en esta çibdat, que la doto e fizo el rey don Alfonç, que Dios perdone, tresahuelo de nuestro señor el rey, cuyo fue el dicho lugar de Orihuela, por preuillegio que dio espresamente a esta dicha çibdat, porque uos agora nueuamente por uos no podedes poner tal pecho contra los nuestros vezinos ni ellos no uos son tenydos de uos pagar cosa alguna por ello" y terminaba requiriendo que diesen por nulos los fiadores presentados por Ferrant Martinez y que en lo sucesivo no demandasen el pago de veintena ni otro derecho alguno, pues en caso contrario "sabet que si al sobredicho nuestro vezino o a sus fiadores alguna cosa les tomaredes sobre esta razon, que nos cataremos manera con la merçed del dicho rey, nuestro senyor, por quel aya cobro e emienda de lo suyo con las costas e danyos que sobre esta razon a el e a nos conuerna a fazer". El consell oriolano tardó casi quince días en responder y, el 3 de marzo, lo hizo con evasivas, alegaba no saber nada de lo que se le reclamaba y echaba la culpa a los almojarifes reales, "et en les regalies del senyor [rey] nos no auem que lliurar, per queus pregam que nos ajats per escusats en la dita raho". 1354-II-18, Murcia y 1354-III-3, Orihuela, ed. Veas Arteseros, Molina Molina 2015. Doc. CI y CII. 
tenían que ver con los sucesos, generalizándose el conflicto en grandes sectores de la frontera castellano-aragonesa.

La dimensión del problema hizo que Alfonso XI y Jaime II iniciaran contactos para ponerle remedio, pero la muerte de éste paralizó las acciones hasta que su sucesor Alfonso IV se reunió con el rey castellano en Tarazona, como sabemos, y alli acordaron también que se cobrase una imposición de dos dineros por libra en las fronteras con objeto de satisfacer a los damnificados. Nacía la "quema" aragonesa y su homóloga la "marca" castellana ${ }^{26}$. términos que definían un impuesto que los castellanos pagaban por todas las mercancías que compraban o vendían en territorio aragonés y los aragoneses en Castilla, que ya funcionaba en diciembre de 1329, cuando Alfonso XI recibió la petición que el concejo de Murcia le había enviado referente a los dos dineros que dan por cada libra los del mio señorio en el regno de Aragon de todas las mercadorias et otras cosas que alla lieuan et, otrosy, los del regno de Aragon en el mio señorio, en el sentido de que los aragoneses estuviesen exentos del pago en Murcia y los murcianos en Aragón, pero el rey castellano demoró su respuesta hasta tratar el asunto con el monarca aragonés en un futuro encuentro, pues al ser un acuerdo entre ambos no podía modificarse unilateralmente, aunque si accedió a que el recaudador en tierras de Murcia fuese Miguel Rallad, cuya residencia en la capital murciana facilitaba el trabajo que hasta entonces realizaba con mayores dificultades Ferrán Martínez, vecino de Cuenca ${ }^{27}$.

El problema de los pagos en uno y otro reino no se solucionó por entonces, pese a las gestiones realizadas por los dirigentes de Alicante ante la reina Leonor ${ }^{28}$,

26. Para regular su cobro, evaluar los daños y asignar las indemnizaciones a los afectados, se nombraron comisarios para el sector fronterizo del reino de Valencia por parte castellana Fernando Martínez de la Torre y por la valenciana Enrique de Quintavalle, y para el sector fronterizo del reino de Aragón Pedro Garcés de Ursa por parte aragonesa, y Marco Fernández de Torre por la castellana. Sobre la "quema", Vid. Canet Aparisi 1983; Canet Aparisi, Navarro Clerigues, Ribera Torrenti 1981-1982; Diago Hernando 2000; Ferrer i Mallol 2005, pp. 522-524; Pino Abad 2014, p. 53.

27. "Sabed que en las posturas que fueron entre mi et el rey de Aragon fue puesto que fasta tiempo çierto pagasen todos los que fuesen del mio sennorio al regno de Aragon de todas las cosas que alla leuasen de cada libra dos dineros, et eso mesmo los que veniesen del regno de Aragon al mio sennorio que pagasen de todas las cosas que troxiesen de cada XX et quatro marauedis dos dineros, et lo que montase en estos dos dineros que fuese para pagar los querellosos del mio sennorio et del regno de Aragon, et para coger et recabdar estos dineros et para pagar los querellosos fueron puestos omes çiertos. Et por esta razon non se podría fazer esto que me uos enbiastes pedir por merçed fasta que yo et el rey de Aragon nos viesemos.

Et por quanto Fernant Martinez, vezino de Cuenca, que a de recabdar estos dineros en ese regno de Murçia fazia grant costa sobrello, por quanto non es desa comarca, tengo por bien que Miguel de Rallad, vuestro vezino, que recabde estos dos dineros que an a dar los del regno de Aragon de cada $\mathrm{XXVII}^{\circ}$ maravedis de todas las cosas que troxieren y a Murçia et que pague a los querellosos del mío sennorio et sennaladamiente a los de Murçia daquello que mostraran en buena verdat de que an de reçebir emienda”. 1329-XII-24, Valladolid, ed. Veas Arteseros 1997. Doc. CXXXVIII.

28. La reina de Aragón, como tutora y adminstradora de los señoríos de su hijo el infante Fernando, recibió las quejas de los alicantinos que juzgaban contrario a los intereses de la población que se cobrase tal imposición en Alicante ya que había motivado que en Murcia se obrase de manera similar, causando un importante quebranto económico a los alicantinos que se desplazaban hasta la capital del Segura para comerciar, y pedían su supresión. Doña Leonor respondió al consell alicantino que Rigo de Quintavall, siguiendo las instrucciones que Alfonso IV le había dado, ordenó que en Alicante todo 
y se mantenía en abril de 1336, cuando Alfonso XI escribió al concejo de Murcia para ordenarle que nombrasen un fiel que cobrase la "marca" a los vecinos de Aragón que viniesen a la ciudad para comerciar y con lo recaudado se indemnizase a los damnificados con anterioridad a la implantación del impuesto y también a los que lo fuesen en adelante, con excepción de los casos en los que hubiese causa judicial, como sucedía con los herederos de Jaime de Moncada ${ }^{29}$.

Junto al impuesto se creó una nueva institución, el alcalde-comisario, sólo existente en la frontera castellano-aragonesa y separado de la jurisdicción del alcalde de las sacas, cuyo objetivo fundamental era vigilar las relaciones entre castellanos y aragoneses, procurando que siempre fluyeran por los cauces de entendimiento y evitar todas aquellas actitudes o acciones que pusieran en peligro la estabilidad fronteriza, lo que explica que sobre el ocupante del cargo recayese además el cobro del gravamen, con lo cual se evitaban los abusos que causaban enfrentamientos que podían ir a más una vez que los afectados acudían ante las autoridades de sus localidades y éstas intervenían ${ }^{30}$.

aquel que de Castilla "aduçia alguna cosa a la dicha villa, pagase dos dineros por libra, por pagar e satisfer a alcunos vasallos del senyor rey de Aragon de alcunas fuerças e roberias que les fueron fechas, segunt se dize, en Castiella. Et que los homens de Murçia e de la senyoria del rey de Castiella, por esta razon, semejantemente, han ordenado e fecha inposiçion en Murçia... que todo home de Alacant que lieue cosa a Murçia, pague dos dineros por libra". La reina no podía suprimir lo que su esposo había ordenado, pero si propuso que si en Murcia "no tomaren ni demandaren daqui adelant a uosotros los dichos dos dineros por libra de la inposiçion, que uosotros tanpoco thomedes a ellos alcuna cosa de la dicha inposiçion, antes entren et salgan en la dicha villa franchos e quitos". 1330-III-25, Barcelona, ed. Veas Arteseros, Molina Molina 2015. Doc. XLIV.

29. El rey respondió así al concejo de Murcia: "Et a lo que nos enbiastes dezir de la marca que toman de vuestros vezinos en Xátiva et en Valencia et en los otros lugares del señorio del rey de Aragon et uos tomades, otrosi, destos logares. Et que nos enbiastes pedir merçed que pudiesedes poner un fiel que cogiese la dicha marca et de la que es cogida et se coge de aqui adelante que mandasemos que ouiesen enmienda los querellosos del nuestro señorio de las que eran ante que fuese puesta la dicha marca, et, otrosi, que ouiesen enmienda los herederos de Jayme de Moncada de los algos que les an tomado en Orihuela por lo de la moneda que nos mandamos pagar a los de Hauanilla......., mandamos que los alcalles et los jurados de y, de Murçia, que pongan un fiel que coga la dicha marca, et de lo que es cogido o se cogera della daqui que primeramente, que sean pagados los querellosos que algun daño auian reçebido ante que la dicha marca fuese puesta et, pagados estos, de lo que fincare que sean pagados todos los otros de la dicha çibdat a quien an tomado o tomaren daqui adelante alguna cosa por la dicha marca". Pero en lo tocante a lo de los herederos de Moncada, decía que no debían ser indemnizados hasta que el pleito se librase. 1336-IV-22, Burgos, ed. Veas Arteseros 1997. Doc. CCCXIII.

30. En el reinado de Alfonso XI debió de unificarse la jurisdicción de la frontera castellanoaragonesa en un sólo alcalde-comisario tal y como estaba en el de Enrique II quien designó, en junio de 1370, a Juan Rodríguez de Torquemada para que fuese "nuestro alcalle-comisario entre los reynos de Castiella e de Aragon, e que vsedes del ofiçio de la dicha alcallia bien e conplidamente, segund que mejor e mas conplidamente vsaron todos los otros que fueron alcalles-comisarios entre los dichos nuestros reynos e de Aragon en tienpo del rey don Alfonso, nuestro padre...fasta aqui". El nombramiento fue ratificado en julio de 1375. 1370-VI-7, Alcalá de Henares y 1375-VII-24, Burgos, ed. Pascual Martínez 1983. Doc. LIII y CLXXXVIII. Juan Rodríguez de Torquemada delegó sus funciones en sus lugartenientes para cada obispado y nombró en los obispados de Cartagena y Cuenca a Alvaro de Lezar (1374) y a Juan Gómez de Chinchilla (1375), quienes a su vez designaron a sus oficiales para que les facilitasen las tareas de inspección y recaudación en los núcleos a los que fuesen destinados. 1374-XII-9, 1375-VI-30 y 1375-VII-31, ed. Veas Arteseros 1985. Doc. LXVII, CXI y CXIII. Sobre esta institución Pascual Martínez 1976. 
En principio la imposición tuvo un carácter temporal, pero en Aragón durante el reinado de Pedro IV se transformó en fija y quedó adscrita al fisco real, por lo cual su evolución fue diferente a la de Castilla ${ }^{31}$. Los problemas derivados de la implantación del impuesto, las quejas de los concejos fronterizos que veían peligrar sus actividades comerciales y los abusos de los recaudadores provocaron una suspensión temporal del gravamen en 1345, pero volvió a ser restablecido en mayo del año siguiente, cuando una nueva comisión redactó unas ordenanzas para regular su cobro en el reino de Valencia y en el sector fronterizo castellano entre Murcia y Moya ${ }^{32}$.

31. Esa diferencia debía de ser la causa de que en Aragón fuesen mas las dificultades para su supresión que era pedida por los mercaderes aragoneses, catalanes y, muy especialmente, valencianos desde el último cuarto del siglo XIV y lograron que María de Luna suspendiese su cobro en 1396 y asi estuvo hasta 1403, año en el que Martín I llegó a un acuerdo con Enrique III de Castilla para reimplantarlo, pero muy poco después se produjo la ruptura comercial entre Castilla y Aragón, que duraría hasta 1409 porque el rey castellano consideraba que los acuerdos establecidos entre Enrique II y Pedro IV no obligaban a seguir manteniendo el impuesto por tiempo indefinido y era partidario de su supresión definitiva. El objetivo castellano de conseguir la supresión de la "quema" estuvo a punto de lograrse en esos años de ruptura comercial que se mantuvo hasta que representantes castellanos y aragoneses llegaron a un acuerdo para poner fin a esa situación que tanto perjudicaba a los mercaderes y comerciantes de uno y otro lado, que contemplaba la supresión temporal del cobro del impuesto, pero la muerte de Martín I, en mayo de 1410, dejó en suspenso las negociaciones y bajo Fernando I se consolidó definitivamente la "quema" en el reino de Valencia, aunque, como señala Diago Hernando, con características muy diferentes a las que había tenido en el siglo XIV. En todo caso, las quejas de los mercaderes y comerciantes castellanos llegaron a las Cortes donde los procuradores solicitaron con insistencia al monarca que interviniese para acabar con este problema que se prolongaba sin que se hiciese nada, y por ello Juan II escuchó en las Cortes de Palenzuela de 1425 a los representantes de las ciudades castellanas que le pedían que atendiese las peticiones que le realizaron en sesiones de cortes anteriores, a las que había respondido que "las yo veria e proueeria", pero al presente nada se había hecho y una de esas solicitudes al monarca "fablaua en razon de la quema o inposiçion que es inpuesta en Aragon en perjuyzio de los mis naturales, que proueyese sobrello, a lo qual yo respondiera que requeriria al rey de Aragon sobre ello para que la quitase e si lo non fiziese que proueeria çerca dello, que fasta aqui non sabiades si yo auia mandado requerir sobre ello, mas que de fecho se leuaua todavia la dicha quema a los mis naturales. Por ende, que me suplicauades que me ploguiese mandar poner por obra lo sobre dicho que me plogo de responder, proueyendo asi en los daños reçebidos como en que se non reçiban mas adelante; otrosi, por quanto muchos de los mis subditos e naturales reçibieron muchos daños e robos e males de los subditos e naturales del dicho regno de Aragon, e fasta aqui non auian auido hemienda nin satisfaçion dello, que, eso mesmo, proueyese çerca dello por tal manera que los mis subditos e naturales fuesen satisfechos e hemendados. A lo qual vos respondo que me plaze de proueer sobre ello lo mas breuemente que ser pueda", lo cual no era sino una nueva larga que daba vida al problema. Diago Hernando 2000, pp. 146-156; González Sánchez 2013, p. 32. RAH 1866, pp. 55-56.

32. La comisión estuvo integrada por Juan Alfonso, abad de Salas, por Castilla, Pedro Ruiz de Azagra por Aragón y Ramón Castellán por Valencia. Las ordenanzas fueron aprobadas por Pedro IV el 24 de mayo de 1346 para que entrasen en vigor desde el 1 de enero de año siguiente y con una duración de cinco años, pero se contemplaba la posibilidad de ampliar el plazo de cobro si para ese límite quedaban afectados por indemnizar. En adelante los mercaderes castellanos que acudiesen a vender, comprar o cambiar mercancías en el reino valenciano, zona muy frecuentada por los murcianos, verían incrementado el arancel que pasaba de 2 a 3 dineros por libra, y se castigaba cualquier fraude con una multa de 6 dineros. El impuesto se pagaba a la entrada y los mercaderes castellanos quedaban exentos de pagarlo a la salida salvo en el caso de que las mercancías que sacasen tuviesen más valor que las que hubiesen traido, abonando en este caso la diferencia entre unas y otras y se insistía en la norma que señalaba que todos los mercaderes castellanos que acudiesen a Valencia a recibir dinero por mercancías que hubiesen vendido en Castilla o Aragón, estaban obligados a pagar "quema" por ellas, excepto que 


\section{HACIA EL ENFRENTAMIENTO DEFINITIVO.}

Cuando el consell de Orihuela en el memorial de agravios que había entregado al obispo de Coria don Pedro de Peñaranda, de cuya mediación hablaré después, le decía:

Senyor, es be que sapiats que les bons homens de Oriola que tenin bestiars en terme
de Murçia auien e an pagat, mes de força que de grau e mes de feyt que de dret, per
aquest any ques conplira per tot lo present mes de deembre asadura, montadgues
e despres altres coses ... les quals coses penyores fon feyts a gran injuria e perju-
diçi dels uehins de Oriola que per dret e per costum antiga de tant de temps que
memoria de omens no es en contrari, auien e deuen auer de erbatges francament e
lliura e sens alguna redempçio en terme de Murçia a llur bestiars coma xi mateix
poguesen auer los de Murçia en terme de Oriola ${ }^{33}$,

invocaba, en efecto, más un deseo que una realidad, pues las relaciones de vecindad se quebraron en el mismo momento en el que se plantó la divisoria político-administrativa, a partir de la cual había que poner la memoria a cero, pues pretender por parte de Orihuela, que se mantuviese la costumbre usada cuando ambas localidades eran parte de Castilla en la realidad que se dibujó tras 1304 era un imposible, porque no se justificaba eso de irse para unas cosas y no para otras, se mirase por donde se mirase.

Era cierto que desde mucho tiempo atrás los oriolanos traían sus rebaños al termino murciano, ya fuese al almarjal de Monteagudo o al Campo de Cartagena, al igual que en reciprocidad hacían los vecinos de Murcia con sus reses cuando se desplazaban a los pastizales oriolanos y más allá. Pero la nueva realidad de Torrellas mostró pronto a unos y a otros que la situación había cambiado, pues cuando viajaban con sus rebaños al territorio vecino ya no se encontraban en el mismo reino, sino que habían pasado de Aragón a Castilla y viceversa y si cuando eran castellanos los de Orihuela podían llevar con facilidad sus animales, por ejemplo, al almarjal de Monteagudo, como se ha visto, ahora todo eran problemas, que tal vez

ya la hubiesen abonado en otro lugar del reino aragonés. Una excepción curiosa al pago es que no tenían obligación de abonar "quema" los castellanos que transitasen por el reino de Valencia con caballos o con moneda de oro o plata sin ánimo de comerciar, porque la salida de ganado caballar y de numerario de plata u oro estaba prohibida de Castilla y, también, de Aragón, salvo en el caso del dinero que fuese la cantidad suficiente para el mantenimiento del afectado, ya que en otros aspectos los recelos del alcalde de las sacas serían muchos y, de no mediar soborno, no dejaría seguir al viajero con mayor cantidad de dinero ni con mas animales que el caballo en que montase y, en su caso, la mula en que transportase el equipaje; en cualquier caso advertir expresamente que no se podía cobrar "quema" por las mercancías que estaba prohibido exportar es una obviedad ya que si no se podían llevar de un sitio a otro no había lugar el impuesto, pero esa inclusión lo que indica es que existía un nutrido tráfico de cosas vedadas sobre la que se exigía la "quema". Finalmente, siempre que fuese para uso personal y no para vender, los castellanos que acudiesen a Valencia para comprar o encargar que les fabricasen vajilla de plata, armas, arneses, etc., estaban exentos del pago, lo mismo que los que comprasen paños para su consumo doméstico y los encargasen en Valencia, aunque si debían pagar "quema" los que sacasen de Aragón paños en bruto. Canet Aparisi 1983, p. 183; Diago Hernando 2000, pp. 110-111.

33. AMO, LA 1, ff. 71v-72r. 
se producían antes, porque el concejo murciano era celoso defensor de su alfoz, aunque ahora su importancia era mayor pues se trataba de rebaños extranjeros, y muy poco dispuestos estaban los ganaderos murcianos a permitir la estancia de ganadería oriolana en la zona comiendo las yeruas e beuiendo las aguas en detrimento de sus propios animales que no hallarían nada que pacer porque los rebaños aragoneses se habían comido las hierbas, además de que había que tener en cuenta los daños que las reses ocasionaban en las zonas sembradas de cereales, sin que, al parecer, los pastores y rabadanes entregasen las compensaciones oportunas, tal y como sucedía con las yeguas que vecinos de Orihuela tenían en el almarjal de Monteagudo $^{34}$ y con los cerdos que Antonio Rufed llevó al Campo de Cartagena unos años antes, aunque parece que en este caso el trasiego ganadero era la tapadera para sacar cerdos de Castilla a Aragón a través de la frontera murciana ${ }^{35}$.

También era usual que vecinos de una y otra localidad o simplemente transeúntes anduviesen en los límites de lo que creían era todavía término de sus respectivos concejos o pensaban estar en el reino castellano y muchas veces sucedía que se adentraban en jurisdicción aragonesa o en tierras en litigio, un hecho favorecido por la propia indefinición de la frontera trazada en 1304. E en ese contexto los actos hostiles por una y otra parte menudeaban en todos los tiempos y un ejemplo es lo que les sucedió a Juan del Corral de Almaguer, Gonzalo de Ocaña y a Alfonso Fernández de Úbeda, quienes expusieron al concejo que ellos estando faziendo carbon en el termino desta dicha çibdad, a la escaleruela desta dicha çibdad, que dizen de Pedro Ruiz, llegaron alli unos vecinos de Orihuela y esgrimiendo que se encontraban en su término les quemaron el dicho carbon e la leña que tenian fecha para fazer el dicho carbon e les auian leuado los destrales e aperos que tenian, y

34. La ausencia de Actas Capitulares murcianas anteriores a 1365 impide conocer las medidas que se pudieron tomar, pero se pueden deducir de lo acordado en la sesión concejil murciana del 13 de septiembre de 1410: " por quanto los vezinos de Oryhuela tienen sus yeguas en el almarjal, termino desta dicha çibdat, comiendo las yeruas e beuiendo las aguas, et los vezinos de la dicha çibdad se quexan mucho dello, por quanto aquellas fazen muchos daños en los panes. Et porque los bestiares de los vezinos de la dicha çibdad no fallan que comer syno en el dicho almarjal, ordenaron.... que los jurados de la dicha çibdad que fagan mandamiento a los señores de las dichas yeguas que las saquen dende luego et que no entren en ningund termino desta dicha çibdad, e sy lo no quisieren fazer, que las traygan aqui a la dicha çibdat et que lieuen dellos la pena que los dichos jurados les pusieren". AMM, AC 1410-1411, f. 59r.

35. En la sesión concejil del 23 de octubre de 1397 se trató el asunto de "los puercos de Anton Rufed, vezino de la villa de Orihuela, que truxo e a traydo y puesto en el Canpo de Cartajena, termino de Murçia, y los pastores que guardan los dichos puercos ponen aquellos a bever en los algibes del alcaçar y en los otros algibes e balsas del dicho canpo e fazen otros muchos daños en el dicho canpo; e avn mas, que an dicho e dado a entender quel dicho Anton Rufed que andaua conprando puercos de cabañas de Castiella para sacar a Aragon. Por esta razon, el dicho conçejo....madaron a Miguel Xixan, jurado clavario del dicho conçejo, e Alfonso Palazol que vayan al dicho canpo e que manden salir del dicho canpo a los dichos puercos que estan en el de la dicha çibdad de Orihuela”. El transporte ilegal de ganado a territorio aragonés desde tierras murcianas, pero esta vez llevado a cabo por vecinos de Murcia, fue la causa de que los citados Miguel Xixan y Alfonso Palazol recibiesen la orden de confiscar "los puercos de Pedro de Jumiella y de Benito Braçenelos e de Salvador Davon, fasta en quantia de cada mil maravedis por quanto se fallo contra ellos que avian vendido los puercos aviendolos engordado en la huerta e los avian vendido a Aragon", tal vez fuesen los que vendieron los cerdos a Rufed. AMM, A.C 1397-1398, f. 87r-v. 
pidieron amparo a los regidores murcianos ${ }^{36}$. Desde Murcia se tomaban medidas para terminar con estas situaciones, pero la repetición de acuerdos similares en los años siguientes es muestra del fracaso de aquéllas y de que el problema persistía y empañaba periódicamente las relaciones entre personas e instituciones del otro lado de la frontera.

Gran parte de los litigios entre murcianos y oriolanos nacían efectivamente de la ya aludida imprecisión fronteriza y a nadie escapaba que la solución estaba en la clarificación de los límites o, en su defecto, en fijar acuerdos con bases sólidas y duraderas. A esto último responde el pacto logrado entre Alfonso Fernández de Saavedra, adelantado de Murcia, Arnalt Dalas, lugarteniente de gobernador, y el consell de Orihuela, quienes por bien de paz e de concordia e que otras discordias e prendas entre nos no puedan seer ni recreçer entre nos de aqui adelante, firmaron en Orihuela, en diciembre de 1336, en el que se abordaban tres aspectos importantes como la actividad comercial, la trashumancia y, finalmente, proporcionar seguridad a todos. El acuerdo se planteaba con una duración de diez $\operatorname{años}^{37} \mathrm{y}$, además, contenía un principio de extradición, pues los malhechores que

36. Juan del Corral de Almaguer fue quien explicó lo sucedido a los regidores y oficiales murcianos y expresó su opinión de que tales actos "los sobredichos vezinos de Oryuela auian fecho en quebrantamiento de la buena paz e buena amistad que es entre el rey de Castiella, nuestro señor, e el rey de Aragon, por lo qual dixo que ge lo daua en querella e les requeria que fiziesen sobre ello lo que cunpla a seruiçio del rey e desta dicha çibdad e no quede syn fazer en ello derecho e justiçia". El concejo ordenó que los jurados junto con los caballeros de la sierra fuesen "a ver a do fue fecho el dicho malefiçio et sy es en termino desta çibdad o de Oryuela" e informasen para que se proveyese lo que fuese conveniente. AMM, A.C 1397-1398, sesión del 23 de octubre de 1397, ff. 58v-59r.

37. Pasados los diez años el acuerdo podía prolongarse por el tiempo que las autoridades de Murcia y Orihuela viesen oportuno. También se establecía un plazo que expiraba el 31 de enero de 1337, durante el cual los afectados de uno y otro lado por prendas y embargos los demandasen y demostrasen para que todo fuese enmendado y una vez expirado ningun afectado sería escuchado. Finalmente, se garantizaba la libre circulación de productos que tanto murcianos como oriolanos podían "pasar, sacar e leuar de la vna parte a la otra, sin enbargo e constrasto ninguno", ya que ni adelantados ni concejos, procuradores ni bailes podían impedir este tránsito sin expreso mandato de los reyes de Castilla y Aragón, quedando aparte, claro está, las mercancías cuya salida estaba prohibida por las leyes de uno y otro reino. En la concordia se establecía que durante la siguiente década "todos los ganados de los vezinos e moradores de Orihuela e de su termino, puedan entrar, estar e andar paçiendo las yeruas e beuiendo las aguas por todo el termino de Murçia, asi en las dehesas como en todo lo al, no faziendo daño, francamente, sin calonia ninguna, et si daño fizieren en viñas, figuerales, panes, senbrados, baruechos, çequias o açarbes, que lo refagan e hemienden a conosçençia de dos omes buenos e, demas desto, que paguen por calonias por cada vez que daño fizieren diez nouenes por cada cabeça de yeguas, potros e bestias mulares e asnares, e de puercos e de ganado vacuno e cabrio, et çinco nouenes por cada cabeça de ganado ouejuno. Et en esta misma manera todos los ganados de los vezinos e moradores de Murçia e de su termino puedan entrar, estar e andar paçiendo las yeruas e beuiendo las aguas por todo el termino de Orihuela, asi en las dehesas como en todo lo al, no faziendo daño, francamiente, sin caloña ninguna, e si daño fizieren en viñas, figuerales, panes, senbrados, baruechos, çequias o açarbes, que lo refagan e hemienden a conosçençia de dos omes buenos e, demas desto, que paguen por caloña por cada vez que daño fizieren seys dineros de reales por cada cabeça de yeguas, potros e bestias mulares e asnares e de puercos e de ganado vacuno e cabrio, et tres dineros de reales por cada cabeça de ganado ouejuno". Quedaba entendido que si alguno de los rebaños oriolanos fuesen asaltados o raptados "por razon de guerra o por otra razon por alguno o algunos" mientras se encontrasen en el término murciano, el concejo quedaba obligado a "salir al apellido, sy se fiziere o fuere sabido con tienpo e fagamos quanto pudieremos por lo tornar, et si fuere leuado 
cometiesen un delito y huyesen a refugiarse al otro lado de la frontera, deberían ser apresados y devueltos al lugar en el que hubieran vulnerado la ley para ser juzgados, tratando de este modo de acabar con la impunidad que ofrecía huir al otro lado de la frontera ${ }^{38}$. También hubo intentos de clarificar el trazado de la línea fronteriza por ambas partes, en octubre de 1441y en el mismo mes de 1462, pero la constante revisión de los mojones demuestra que no era cosa fácil ni perdurable ${ }^{39}$.

ascondidamente o a furto que seamos tenudos de demandar el dicho ganado e fazer quanto podamos e deuamos por lo cobrar por razon del quebrantamiento del termino a costa e mesion de aquel de quien fuere el dicho ganado", y lo mismo se establece para el caso de que los ganados de vecinos de Murcia fuesen asaltados o robados en el término de Orihuela. 1336-XII-19, Orihuela, ed. Veas Arteseros, Molina Molina 2015. Doc. LXI.

38. La frontera murciano-oriolana era un espacio frecuentado por gentes cuyo medio de vida era el asalto que realizaban al otro lado de la divisoria, sobre todo a los pastores y rebaños en campos abiertos, comerciantes y viajeros en los caminos y también estaban dentro de su alcance pequeños lugares con población musulmana, como Fortuna, Abanilla y Ricote, en el lado murciano, y Elche, Crevillente y Albatera en el oriolano, en los que apresaban islámicos bien para canjearlos en la frontera de Granada, caso de los fronterizos murcianos, o para venderlos en los mercados de esclavos, caso de los oriolanos, cuyas acciones más lejanas les llevaban hasta la frontera de Granada, muy especialmente por la zona fronteriza con los Vélez donde actuaba el fronterizo oriolano Andrés de Benavent. Tras la acción, la rápida huida hacia sus lugares de residencia con el botín obtenido, ya fuese productos, reses o personas, les aseguraba no ser perseguidos y apresados una vez cruzada la divisoria. Esa impunidad se podía combatir con acuerdos y por ello el adelantado de Murcia y el lugarteniente de gobernador de Orihuela "porque justiçia sea fecha e conplida en los malos e los buenos biuan en paz e en asosiego ... ordenamos e ponemos que qualquier o qualesquier malfechores que algun malefiçio fizieren en el vn logar e en su termino e se fueren al otro, que sean enbiados e remetidos con todo lo que leuaren al logar donde vinieren e salieren, porque en aquel logar do lo fiçieron fagan e cunplan su fuero e su derecho antel juez o juezes daquel logar do fuera o fiziera el malefiçio. E esto de la remision de los malfechores que lo mande yo, dicho adelantado, asi guardar e conplir daqui adelante a todos los logares que son del mi adelantamiento que fazen e faran por mi, et yo dicho procurador que lo mande, otrosi, asi guardar e conplir daqui adelante a todos los logares que son de la mi procuraçion que fazen o faran por mi”. 1336-XII-19, Orihuela, ed. Veas Arteseros, Molina Molina 2015. Doc. LXI. Vid. sobre estas cuestiones fronterizas Culiáñez Celdrán 2015, pp. 24, 26 y 65; Veas Arteseros, Serrano del Toro 2016, p. 1336. Los cambios políticos que se produjeron en Castilla en 1350 y el giro de la política respecto a Aragón que trajo la llegada al poder de Pedro I no facilitaron la prolongación del acuerdo, de modo que, pasada la "Guerra de los dos Pedros" y normalizadas las relaciones con Aragón, Juan I y Pedro IV volvieron a plantearse este problema de la extradición y encomendaron a Juan Sánchez Manuel, adelantado mayor del reino de Murcia, y a Bernat de Senesterra, gobernador de Orihuela, respectivamente, para que dirigiesen las comisiones encargadas de elaborar un acuerdo que, después de casi dos años de deliberaciones, fue firmado en Orihuela el 29 de enero de 1382 y ratificado en Murcia cinco días más tarde, el 3 de febrero, una vez que el concejo de Lorca, que también se sumaba, lo aprobó. Veas Arteseros 1990, pp. 50-59.

39. En octubre de 1441 una comisión bilateral amojonó la divisoria desde Beniel: "Que se tomase la raya que parte los dichos terminos en la huerta ayuso de Benifiel asy como comiença del rio de Segura la via de la mar a la parte del medio dia, linea derecha fasta salir del regadio et entrar en el monte, et ally fuese fecho vn mojon dexando la cañada de Marçelot e de Linares a la parte Orihuela e la Cañada Ancha a la parte de Murçia, et deste primero mojon vaya la linea derecha al Portichuelo de Entordera et que se faga en el dicho Portichuelo de Entordera vn mojon, quedando la Fuente de Entordera a la parte de Orihuela. Et desde el dicho mojon del dicho Portichuelo de Entordera sea tomada linea derecha fasta la Fuente Amarga e que sea fecho ally otro mojon et que sea tanbien auido por mojon la dicha fuente e comuna a amas partes. Et que de la dicha Fuente Amarga vaya la linea derecha a la Majada de las Vacas que es en el cabeço de la Balsa de la Pinilla, et que sea fecho ally otro mojon quedando la dicha balsa a la nuestra parte. Et que del dicho mojon de la Majada de las Vacas sea tomada 
A estas cuestiones se sumaron otras derivadas de la decisión del infante Fernando de Aragón, señor de Orihuela, de modificar la contribución que los oriolanos tenían que pagar por las tierras que poseían, pero el consell incluyó en la obligación a todos aquellos foráneos que fuesen propietarios de parcelas en el término de Orihuela, es decir, la medida afectaba a numerosos vecinos de Murcia

vna via al alcor ençima del escaleruela que los de Orihuela dizen de Pedro Royz et nosotros dezimos de Los Carboneros, et ally sea fecho otro mojon. Et de ally sea tomada derecha via al Pozo de las Siete Figueras et que sea fecho ally otro mojon, quedando el dicho pozo comun et por mojon entre amas partes. Et que desde el dicho pozo e mojon de las Siete Figueras vaya derecha linea a la çeñuela del pinatar et que sea fecho ally otro mojon, quedando la dicha çeñuela comuna e por mojon entre amas las dichas partes. Et de la dicha çeñuela sea tomada via derecha a la mar do sera la mediania del terminillo e confin et espaçio que es entre el Pinatar et el Ginebrar, et sea fecho en la dicha mediania del Ginebrar et Pinatar vn mojon, quedando el Pinatar con todo lo al de la mano derecha de la dicha linea e mojones, como se va del rio de Segura a la mar, a esta çibdad, et el Ginebrar con todo lo al de la mano siniestra de la dicha linea e mojones del rio a la mar a la çibdad de Orihuela".

Por otra parte, en octubre de 1462, otra comisión fijó los mojones que delimitaban los términos respectivos por Santomera y Campo de la Matanza, según lo siguiente: "Primeramente, que se tomase la raya que parte los dichos terminos en la huerta, asy como comiença del rio de Segura la vya de la Sierra de Santomera, linea derecha fasta salir del regadio et entrar en el rayguero e en el camino, cerca del dicho rayguero fuese fecho vn mojon enfrente de vna senda que parte e va entre los labrados de amas las dichas çibdades, e que la dicha senda sea raya e parta terminos entre las dichas çibdades de Murçia e de Orihuela, la qual dicha senda sea comuna asy como lo es entre amas dichas çibdades. Et deste primero mojon vaya la línea derecha a la çeñuela, la qual es et cae en la heredad de Santomera, que es de la dicha çibdad de Murcia, et que sea fecho en la dicha senda, delante de la dicha çeñuela, otro mojon. Et desde este dicho segundo mojon sea tomada linea derecha fasta vn çerramiento que esta fecho en la boca del Açarbe Viejo, llamado de la Puerta de Murçia, que es en la dicha çibdad de Orihuela, que sea fecho ally otro mojon. Et que deste mojon terçero vaya linea derecha fasta el canto del dicho rio de Segura, çerca del camino real que viene de Orihuela a Murçia, llamado el Camino de Enmedio, et que sea ally fecho otro mojon. Et que los dichos mojones sean fechos de piedra e de mortero en los dichos lugares citados et señalados a costa et mision de la dicha çibdad de Orihuela.

Et, otrosi, para ver et praticar e concordar et fazer la declaraçion de los terminos de la parte del Canpo de la Matança desde la sierra que es entre la dicha Santomera et el dicho canpo fasta llegar al termino do parten la dicha Orihuela e la dicha Hauanilla ... Primeramente, que en medio de los dos barrancos que dizen del Azenbuchar, que son en la sierra que es entre el dicho Canpo de la Matança et la dicha Santomera, sea fecho vn mojon et el vn barranco ques faza la dicha çibdad de Murçia con sus vertientes, sea avido por termino de la dicha çibdad de Murcia, et el barranco ques faza la dicha çibdad de Orihuela sea termino de la dicha çibdad de Orihuela. Et deste primero mojon vaya linea derecha et en el llano del dicho canpo sea fecho otro mojon. Et desde este segundo mojon vaya linea derecha al dicho cabeço que es en medio del dicho canpo, que los de Orihuela dizen del Atalaya e nosotros dezimos El Negro, et ençima del dicho cabeço, en el medio del, sea fecho otro mojon, e las vertientes del dicho cabeço a la parte del leuante sea avido por termino de Orihuela et las vertientes del dicho cabeço faza sol poniente sea termino desta dicha çibdad de Murçia. Et del dicho mojon terçero del dicho Cabeço del Atalaya vaya linea derecha fasta el Cabeço Gordo, ques en el dicho canpo, en medio del qual dicho Cabeço Gordo, en la cunbre del, sea fecho otro mojon, e las vertientes del dicho cabeço faza leuante sea termino de la dicha çibdad de Orihuela et las vertientes del dicho cabeço faza sol poniente sea termino desta dicha çibdad de Murçia, et que la balseta ques entre los dichos dos cabeços a la parte del leuante sea comuna a amas las dichas çibdades de Murçia et Orihuela. Et del dicho mojon del dicho Cabeço Gordo vaya derecha linea fasta dar en la raya de los terminos que son entre la dicha çibdad de Orihuela et la dicha Hauanilla, sea otro mojon. E que estos mojones de suso declarados a la parte del dicho Canpo de la Matança se fagan a costa de amas las partes de cal et de canto porque sean mas estables et duraderos..." 1441-X-24, Murcia. AMM Pg Núm. 131. El documento firmado en Orihuela, 1441-X9, Orihuela, AMM Pg Núm. 132. 1462-X-12, Murcia, AMM Pg Núm. 140. El documento firmado en Orihuela, 1462-X-10, Orihuela, AMM Pg Núm. 139. Vid. Barrio Barrio 2012, pp. 1061-1064. 
quienes comparecieron quejosos ante el concejo que intervino cerca del infante y éste ordenó al consell que no exigiese a los de Murcia contribución por los heredamientos o posesiones que aquellos en la dicha uilla e sus terminos an e poseen ${ }^{40}$.

La desaparición de Alfonso XI y el relevo en el trono castellano desde el 26 de marzo de 1350, trajo importantes cambios pues los planteamientos políticos de Pedro I respecto a Aragón no eran ni mucho menos los de su padre y pronto se produjo un aumento de la tensión entre ambos reinos, cuyo punto culminante en la demarcación fronteriza murciano-oriolana llegó en los años cercanos al estallido de la guerra, cuando, el 29 de noviembre de 1354, el pregonero del consell anunció la expulsión de todos los de Murcia que viviesen o se encontrasen en Orihuela en el plazo de 24 horas y la prohibición de que regresasen bajo ningún concepto, con la advertencia de que, pasado el plazo, todos los que fueren hallados serían

40. 1353-XII-21, Cuenca, ed. Veas Arteseros, Molina 2015. Doc. XCII. La carta del infante fue recibida en Murcia y el concejo despachó a Guillén Celdrán y a Gonzalo Meléndez para que la presentasen ante el consell de Orihuela y tratasen allí la solución de este conflicto, tal y como hicieron el 11 de enero. Dos días más tarde los dirigentes oriolanos respondieron diciendo que no eran obligados a cumplir el mandato del infante, porque fue obtenido callada la verdad y porque era contra el privilegio que poseía Orihuela por el cual todos los vecinos y otros cualesquier que poseyesen bienes y heredades en el término oriolano contribuyesen a las cargas fiscales, y los de Murcia estaban en esa situación, y más por cuanto así lo había mandado el infante por su carta, librada en Valladolid, el 15 de junio de 1353, de la cual los delegados murcianos no hacían mención y por el mandato que traían no se entendía revocada, ratificándose en que no "es tengut....obeyr ni cunplir" 1354-I-6, Murcia, 1354-I-11, Orihuela y 1354-I-13, Orihuela. Ibid. Doc. XCIII, XCIV y XCV. No serían los de Murcia los únicos, ya que los de Elche que poseían bienes en Orihuela, según las órdenes del infante, pagaban el sextuplo de lo establecido para los vecinos oriolanos, aunque finalmente el consell los equiparará. Ramón Pont 1983, p. 71. Cabe pensar que los de Murcia que poseían bienes en suelo oriolano se vieron afectados por otra disposición del consell que había acordado hacer una derrama de 20.000 sueldos para contribuir a la boda del infante don Fernando con María de Portugal, ya que sabemos que los bienes de los no vecinos también fueron incluidos en el padrón de tasaciones y valorados dos veces más que los que poseían los vecinos de Orihuela, tal y como lo declaraba Juan Jiménez de Perencisa en la misiva que envió a los oficiales del consell: "Ya sabedes en como echastes taja per a conplir los uint mill soldes que mandastes en seruiçio et ayuda de las bodas del senyor infant et tachastes los bens de los que no son uezinos las dos partes mas que de los uezinos", por lo cual les pedía que como su futuro yerno, Luis Seguí, sería vecino de Orihuela, tal y como constaba "en las cartas del esposaliçio del et de mi fija donase todos los dichos bens a mi fija e prometiese et afirmase que celebrado el matrimonio tendria su domiçilio mayor en Origuela e seria uuestro uezino", le permitiesen "quel dicho Loys contribuesca con uos por lo que y a segunt uezino", con lo cual pagaría menos. En todo caso, el acuerdo del consell del 27 de junio era claro: "Item, fon ordenat en raho dels estranys que son terratinents en la uila d'Oriola que sia enantat en raho de lo que an a pagar en la ajuda dels vint mill soldes quel consell fa de seruiçi al senyor infant que paguen segons la carta e manament del dit senyor infant". Las quejas de muchos de los afectados llegaron al consell que se mantuvo firme en su decisión y el 10 de julio, en respuesta a un escrito de alegaciones presentado por Guillen Lleona, procurador de Bertrand de Canelles, cuyos bienes y censos fueron tasados a efectos de la contribución matrimonial en 15.000 sueldos, cantidad que juzgaba excesiva e indebida, porque alegaba que estaban exentos de todo servicio, indicó que los 20.000 sueldos "fosen pagats per tots los uehins e hauitadors e terra tinents del dit lloch e del terme de aquella", por lo cual los murcianos que poseían propiedades urbanas o rústicas en Orihuela y su término debían contribuir a la boda del infante. De todos modos, hubo exenciones como la otorgada por don Fernando a Ramón de Rocafull, pues ordenó al consell desde Cuenca, el 10 diciembre de 1353, que no le demandase cantidad alguna. 1354-VI-11, Elda, 1354-VI-27, 1354-VII-10 y 1354-VII-29. AMO, LA 1353-1356, A-1, Docs. Sueltos y ff. 45r, 50r-v y 52r-v. Bellot 2001, 1, pp. 23-24, 2, p. 244; Ramón Pont 1983, pp. 69-71. 
presos e recabdados con todo lo que touiesen y también se amenazaba a quienes los amparasen u ocultaren. Esta decisión que preconizaba un ambiente prebélico, sorprendió a Juan Vázquez, lugarteniente de Juan Fernández de Orozco, adelantado mayor, quien escribió a Juan Sánchez de Ayala ${ }^{41}$, procurador de Orihuela por Fernando de Aragón, y al consell, para que certificasen la realización del pregón y sus causas, a la vez que les pedía que prolongasen el plazo para la salida de los murcianos que quedasen y que pudiesen venir a Murcia salvos y seguros ${ }^{42}$. La acción oriolana tuvo su réplica en Murcia donde el concejo tomó una medida similar.

41. Juan Sánchez de Ayala era, según Torres Fontes, hijo natural del adelantado de Murcia Pedro López de Ayala y de Inés de Azagra y hermano de Pedro López de Ayala y Azagra y de otras y otros más habidos de dicha unión y que serían los herederos de las propiedades paternas en territorio murciano, centradas en la huerta de Murcia. Las noticias que tenemos sobre él son escasas ya que carecemos de Actas Capitulares murcianas en la primera mitad del siglo XIV y primer decenio de la segunda, por lo que es la documentación oriolana la que nos lo presenta como Procurador General de Orihuela por el infante don Fernando, cargo que ocupaba en 1353 y que mantendría hasta el 9 de febrero de 1354, dia en que se recibió en el consell oriolano una misiva del infante por la que nombraba a Ramón de Rocafull. Respecto a la guerra entre Pedro I y Enrique de Trastámara se mantuvo fiel a éste y tras la muerte del rey en Montiel adquirió protagonismo político y fue nombrado adelantado de Murcia y recibió el encargo de apresar a todos los petristas de la ciudad, en especial Pascual Pedriñán, otrora poderoso tesorero de Pedro I. Poco tiempo después dejó el cargo para el que Enrique II nombró a su hermano Fernán Pérez que sería relevado casi de inmediato por Juan Sánchez Manuel, conde de Carrión. Ya había muerto en 1375. Vid. Ramón Pont 1983, p. 71; Torres Fontes 1976, pp. 15 y 18.

42. 1354-XI-30, Murcia, ed. Veas Arteseros, Molina Molina 2015. Doc. CIII. El consell respondió a la misiva del lugarteniente de adelantado y concejo de Murcia, en términos inequívocos:

"Als honrrats en Johan Uazques, tinentlloch de en Johan Ferrandez de Foroçco, adelantat del regne de Murçia, e al consell de la çiutat de Murçia. De nos lo consell, justiçia, jurats e prohomens de Oriola, salut ab tota honor.

Fem vos saber que ueem una carta per uos tramesa al honrrat en Johan Sanchez de Ayala, procurador en los llochs que el molt alt senyor infant don Ferrando te en part del regne de Valençia de ça Sexona, la qual a ell e a nos fos presentada per la qual nos fahiets saber que us auien dat a entendre que nos auiem feyt fer pregons en Oriola que tots e qualsquier uehins e ahuitans de la dita çiutat e de son terme fosen exits de Oriola e de son terme a dia çert e que de aqui auant que qual quier dells que $\mathrm{y}$ fosen trobats que y serien preses e recabdes ab tot ço que y tinguesen, et que nengu om de açi no los tingues incubrets sots certa pena. Per la qual cosa marauellats uos de aquestes coses que requeriets de part de uostre senyor lo rey et en pregueuets de la uostra que us enuiasem çertificar del dit prego e de la raho que nos heren moguts a fer aquell. Et si alguns uostres vehins auia açi que les donasem terme sufiçient que poguesen anar saluus e segurs, segons que tot aço en la uostra carta pus llargament ueem esser contegut.

A la qual uostra carta per la present responem e dehim uos que es çerta cosa quel dit procurador ha feyt tancar les portes de Oriola als vehins e ahitadors de Murçia, per tal manera que alguna persona de qualseuol lley o condiçio sia no sia osat acullir a homens de Murçia en Oriola ni en son terme ni encobrir ni tenir aquells aqui ni traer de Oriola ni per Oriola ni per son terme per menar a Murçia o portar en Murçia ni de uehins de Murçia, caualles, armes, or ni argent ni alguns altres aueries ni coses ni bens. Et aço, sots çertes penes per ell en la sua crida expresades, la qual crida el dit procurador ha feyta per justes e rahonables causes e rahons que le an mogut a fer aço e les quals defallir no podia, et de les quals el, si mester sera dara raho a nostre senyor el infant don Ferrando, totauia que es pertanga e sera merçe sua de saber ho. Et creem çertament que aço ha feyt per gran seruei del dit senyor e per be e profit dels seus sotsmesos.

Datis en Oriola, dos dias de deembre anno Domini $\mathrm{M}^{\circ} \mathrm{CCC}^{\circ} \mathrm{L}^{\circ}$ quarto. AMO, LA 1353-1356, A-1, ff. 65v-66r. Ramón Pont 1983, p. 73. 


\section{EL ÚLTIMO INTENTO DE PAZ. LA MEDIACIÓN EPISCOPAL}

El agravamiento del conflicto entre Murcia y Orihuela sorprendió al nuevo obispo de Cartagena Alfonso de Vargas quien había llegado a la sede poco tiempo antes y que, precisamente, se encontraba en Orihuela en septiembre de $1352^{43}$, pero estaba claro que el prelado era un castellano muy ligado a Pedro I y, aunque ese fuese su deseo, no podía aparecer como neutral a los ojos del consell en una cuestión política, precisamente en aquellos momentos en los que Orihuela estaba bajo el entredicho lanzado por el arcipreste de la localidad ${ }^{44}$, hecho que, una vez más, ponía de relieve el grave problema que, como señalaba Pedro Bellot, representaba que Orihuela y su gobernación perteneciesen a una jurisdicción eclesiástica castellana ${ }^{45}$.

El obispo de Cartagena, tal vez apoyado por el concejo de Murcia, pensó en su antecesor para realizar esta función mediadora, ya que Pedro de Peñaranda conocía muy bien estas tierras y a sus hombres en las que había residido y con los que había convivido largos años durante los cuales se había enfrentado tanto a murcianos como a oriolanos ${ }^{46} \mathrm{y}$, vuelto de su nuevo destino en la sede de

43. Desde la capital oriolana comunicó a todos los clérigos del obispado que había concedido una indulgencia de cuarenta días a todos los fieles que diesen limosna para costear las obras de las torres del campo de Lorca. 1352-IX-22, Orihuela, ed. Torres Fontes, Torres Suárez 1984, pp. 174-176; Veas Arteseros, Molina Molina 2015. Doc. LXXXVI.

44. En diciembre de 1354 el arcipreste de Orihuela había puesto entredicho en la localidad a causa de la confiscación de bienes eclesiásticos realizada por Jaime Maestre y, pese a que el consell intentó la mediación de Juan Martínez de Canales, arcediano de Lorca y vicario episcopal, éste mantuvo la sanción hasta que se realizasen las oportunas satisfacciones económicas a la Iglesia, tal y como informaba Juan Sanchez de Ayala, procurador de Orihuela, a Juan Jiménez de Perencisa, baile general del señorío del infante Fernando, cuya intervención solicitaba: "per ço pregam uos que trametets e hordenets ab lo en Jacme Maestre en tal manera que la dita confiscaçio sia restituida com lo arcipreste sia aparellat de fer paga de tot ço que es degut de prinçipal.....en altra manera diu quel dit enterdit per nengun cas no releuaria, perque us pregam que endreçets que pus som christians que viuan a ley de christians" y fuese posible enterrar a Felipe Togores en el hospital de San Saluador y se restableciesen las celebraciones divinas. 1354-XII-5, Orihuela. AMO, LA 1353-1356, A-1, ff. 68r-v. las cartas del consell y las respuestas de arcediano, 1354-XII-13, Orihuela, 1354-XII-17, Murcia, 1354-XII-20, Orihuela y 1354-XII-21, Murcia, ed. Veas Arteseros 2002, pp. 1110-1113; Veas Arteseros, Molina Molina 2015. Doc. CVII-CX. Sobre la actitud de don Alfonso de Vargas respecto a Pedro I y Orihuela, Vid. Arranz Guzmán 2000, p. 252.

45. El gran cronista oriolano indicaba que "Fue grandísimo descuido de los de Orihuela el dia que se dividió el reino de Murcia por la sentencia arbitraria de don Dionis, rey de Portugal, y los otros, no dividirla también en lo espiritual como en lo temporal, o erigiendo su Iglesia en catedral o a lo menos, agregándola a Valencia... Costó este descuido a Orihuela innumerables ducados, infinitas pesadumbres, muchos entredichos y descomuniones, que como casi todos los obispos eran castellanos, por cualquier mínima ocasión echaban mano a las armas espirituales; y aún los que no fueron castellanos, como don Guillen Guimiel y el converso Paulo Burguense, con ser tan buenos prelados nos dieron harta pesadumbre". Bellot 2001, 2, p. 33.

46. Inició su pontificado en la sede cartaginense en 1329 y el rigor con el que se conducía e imponía sus decisiones hizo que protagonizara fuertes enfrentamientos con el consell oriolano y con el concejo de Murcia que fueron castigados con el entredicho y la excomunión, lo que provocó varias intervenciones de Alfonso XI para que suavizara su proceder y levantara las censuras eclesiásticas con las que castigaba la desobediencia de los fieles de su obispado. Sus visitas a Orihuela eran frecuentes 
Coria ${ }^{47}$, escribió al consell oriolano desde Murcia, el 4 de diciembre de 1354, lo que implica que no murió de peste en $1349^{48}$, y les indicaba que conocía los sucesos y que se ofrecía como mediador para buscar una solución que fuese:

\begin{abstract}
el pro de la tierra e de cada vno destos lugares, asi como aquel que fuemos cada luengamiente en ella, et amamos e preçiamos a todos e a cada vno de uos, por esto queremos trebajar nos entre uosotros de auenir estos fechos, porque entre uos e ellos no se recreciese alguna cosa contraria.
\end{abstract}

Y para ello les pedia que formasen una comisión para que se entrevistase con él en Santomera o en otro lugar donde pudiese acudir y hablar con Juan Sánchez de Ayala ${ }^{49}$. El procurador y el consell debatieron tras la llegada de la carta y, finalmente, acordaron que en la mañana del sábado, 6 de diciembre, los enviados de Orihuela se encontrarían con el prelado curiense en el cabeçal de Santomera, terme de Oriola, lo qual loch auem acordat per escusar los forts camins que son dins la terra, tal y como fue notificado a Peñaranda el viernes, día $5^{50}$. La entrevis-

y precisamente una de ellas provocó el aplazamiento del sínodo convocado para el viernes 25 de noviembre de 1331, pues los asuntos oriolanos requirieron la presencia del obispo alli más tiempo del previsto, razón por la cual el sínodo comenzó el domingo, 27 de dicho mes: "Por razon que el viernes, que devieran començar, era en Orihuela e non pudo venir fasta el sabado en la noche". Sanz Sancho 2002, p. 82; Torres Fontes 1998, p. 669.

47. El 12 de febrero de 1354 ya había llegado a Coria don Pedro de Peñaranda, procedente de tierras murcianas y seis dias después, el 18 de febrero, se comprometía a pagar los 444 florines correspondientes a los servicios comunes que tenían que pagar los obispos de Coria a la Cámara Apostólica. Arranz Guzmán 2001, pp. 441-442.

48. El Profesor Torres Fontes afirmaba, refiriéndose a la epidemia de peste, que "Sabemos que uno de los fallecidos fue el obispo don Pedro de Peñaranda, cuya herencia preocupó a Alfonso XI, pues desde el sitio de Gibraltar, el 10 de julio de 1349, daba poder al doctor Juan Fernández, su alcalde, para que se hiciera cargo de los bienes del obispo don Pedro, "que agora finó". El mismo parecer fue seguido por Amasuno quien, al hablar de la epidemia de peste que asolaba el reino de Murcia en 1349, decía que "Entre sus víctimas más notorias hay que contar la de su obispo Pedro de Peñaranda, cuya herencia es gestionada por el mismo rey Alfonso, pocos meses antes de que él mismo, en el sitio de Gibraltar, sufriera la misma suerte". Al error contribuyó Diego de Comontes, obispo de Cartagena, quien decía que Peñaranda "tandem plenus dierum defunctus est et in dicta Ecclesia sepultus, jacet in dicto choro coram Cathedra Episcopali". Amasuno 1994, p. 27; Torres Fontes 1998, pp. 669-670; 1981, p. 15; Torres Fontes, Molina Molina 2009, p. 11; Veas Arteseros 1997. Doc. CDXXXIII. Asi, pues, no era Pedro de Peñaranda a quien se refería Alfonso XI, ni su cuerpo fue sepultado en el coro de la catedral murciana. Trataré esta cuestión en un próximo trabajo sobre este prelado.

49. "Porque uos rogamos que tengades por bien que algunos omnes buenos de uos con el procurador vos querades veher con nos en Santomera o en alguno desos otros lugares en vuestro termino, do uos entendieredes que nos podieremos yr al procurador e a uos porque fablemos sobre estos fechos, que la nuestra intencion es buena et creemos que en ello seruimos a Dios e a los senyores de la tierra. Et de como acordades de fazer, enbiat nos vuestra respuesta porque sepamos en como auemos de façer; et desta misma raçon enbiamos nuestra carta al procurador". 1354-XII-4, Murcia, ed. Veas Arteseros, Molina Molina 2015. Doc. CIV.

50. 1354-XII-4, Murcia y 1354-XII-5, Orihuela, ed. Veas Arteseros, Molina Molina 2015. Doc. CV. También el día 5 Juan Sánchez de Ayala escribía a Juan Jiménez de Perencisa y a Martín de Segarra, consejero del infante Fernando, para informarles acerca de la mediación del obispo de Coria y "que nos auem acordado que dema [de matina]da uolent nos dit procurador e alguns prohomens anar nos [ueure] ab lo dit senyor bisbe per oyr e entendre ço quens uolra dir et demostrar e reebre en acord la 
ta entre el prelado y la comisión oriolana que presidia Sánchez de Ayala se celebró y Pedro de Peñaranda recibió las explicaciones y causas por las cuales existía esa gran tirantez entre Murcia y Orihuela, a juicio de los miembros del consell quienes impusieron como paso previo a cualquier negociación que los regidores murcianos ordenasen la restitución de todos los bienes tomados a vecinos de Orihuela $\mathrm{y}$, en su caso, el abono de las indemnizaciones a que hubiere lugar a quienes no fuesen devueltas sus pertenencias. Si no era asi, no había nada que hablar.

Pedro de Peñaranda lo tenía difícil porque las exigencias del consell chocaban con la política impositiva de Pedro I cuyas peticiones a los concejos ${ }^{51}$ implicaban dispendios que, como el de Murcia, tenían que cubrir y la ganadería y el comercio eran dos importantes fuentes de ingresos, por lo que los recaudadores de los derechos concejiles ponían celo en que todos pagasen, y a ello se añadían los asaltos y robos cometidos en campos y caminos por vecinos de diferentes localidades en represalia por las incursiones que almogávares de la gobernación realizaban en territorio murciano casi siempre en busca de mudéjares, vecinos de alguna de las morerías del adelantamiento, que luego trataban de vender en el mercado de esclavos de Valencia, donde también iban a parar los granadinos que lograban apresar, originando serios problemas, sobre todo a Lorca en cuyo término, no en tierra granadina, frecuentemente los capturaban ${ }^{52}$. Pero, sobre todo, el prelado cauriense se enfrentaba a un ambiente enrarecido por los constantes rumores sobre preparación de ataques contra Orihuela y apresto de guerra realizados desde Castilla, cuyo rey ya no disimulaba su hostilidad a Aragón y la amenaza para Orihuela, naturalmente, vendría desde Murcia.

Pedro de Peñaranda abandonó Santomera y al poco de llegar a Murcia convocó a través del portero concejil a los dirigentes murcianos para que "saliente de viesperas" se reuniesen con él en su posada y les pudiese exponer lo hablado con los de Orihuela, pero por enbargos que ouieron aquella noche, segund nos dixeron algunos de los dieç, non se pudieron ayuntar y la reunión fue aplazada para el domingo

resposta sobre dita". Jiménez de Perencisa respondió desde Novelda e insistía en que los representantes oriolanos expusiesen al prelado todos los atropellos que habían recibido y recibían de Murcia, justificación suficiente para adoptar las medidas decretadas: "mas lleuar les dits afers ab lo dit bisbe per belles paraules encarregati uos contra consell de Murçia dels gros e enormes greugues, dans e perjudiçis que auets reebuts segons es çert e manifest a Deu e als xentes, car çert es que tot nos per que el bisbe si non sies a instançia e requesta del consell de Murçia o singulars de aquella”. 1354-XII-5, Orihuela, 1354XII-6, Novelda. AMO, LA 1353-1356, A-1, ff. 68r y 69r.

51. Entre ellas las militares, pues en julio de 1354, ordenaba al concejo de Murcia que le enviase 130 ballesteros de ellos 50 "de la nómina", pagados por el concejo, y los restantes con cargo al fisco regio. 1354-VII-28, Villarreal, ed. Molina Molina 1978. Doc. 84.

52. Hoy creo que no hay duda de que la invasión aragonesa que dirigió Jaime II tenía como objetivo que Aragón recuperase la frontera con Granada que el Tratado de Almizra le había quitado. Torrellas no cumplió ese objetivo, pese a lo cual el consell de Orihuela esgrimía con frecuencia su posición fronteriza con el reino nazarí, porque desde el fallo de 1304 era la referencia aragonesa respecto a Granada, lo que explica afirmaciones sobre la amenaza que significaba la proximidad de la frontera granadina, “... encara en frontera de moros del regne de Granada, los quals son a prop de la dita uila quize legues..." o “... com per los mals e dans que la dita uila reb de cascu día axi per enemichs de la fe...". 1417-XII-31, Orihuela y 1400-VIII-3, Orihuela. AMO, LA 1418, A-17, f. 24r y 1400, A-10, f. 69v. Vid Culiáñez Celdrán 2015; Jiménez Alcázar 2010; Marzal Palacios 2006; Serrano del Toro 2015. 
por la mañana. El prelado les expuso entonces todo lo hablado en Santomera y como, en señal de buena voluntad, el consell le había prometido que revocarían en todo el pregon que auia mandado façer el procurador, y les rogó que en gesto de reciprocidad suspendiesen las medidas similares adoptadas en Murcia con lo cual harían honor a los compromisos que había adquirido con los representantes oriolanos y no lo dejarían en mal lugar. Hubo debate, pero el mediador no logró arrancar de los regidores murcianos ningún acuerdo y si la necesidad de tomar un tiempo para ver qué hacer, con lo cual terminó la reunión.

La posición del concejo en ese ambiente generalmente hostil dejaba muy poco espacio a la esperanza de una relajación de la tensión murciano-oriolana, imposible cuando, en la tarde del martes, 9 de diciembre, el pregonero recorría las calles de Murcia para publicar el acuerdo concejil por el cual se ordenaba que todos los vecinos de Orihuela sacasen inmediatamente sus rebaños del término murciano y lo mismo tenían que hacer con los bienes que en él tuviesen. No le quedaba otra cosa que hacer a Pedro de Peñaranda que notificar, el día 10, todo lo sucedido al consell e insistir en que anulasen las medidas que habían tomado contra Murcia, tratando de mostrar que, pese al pregón efectuado, había voluntad de mantener la paz por parte del concejo murciano que había ordenado devolver los carneros que las guardas habían tomado al ganadero oriolano Jaime Vidal. En cualquier caso, las palabras del obispo:

et si nos falleçiemos en lo que vos prometiemos rogamos vos que nos perdonedes, que Dios lo sabe que non seria por no dar luengas e dilaçiones a estos omes buenos que lo quisiesen conplir, mas non se pudo ante façer por algunos enbargos que se $y$ recresçieron,

sonaban a fracaso y mucho más cuando terminaba diciendo Et luego tenet por bien de dar recabdo por que los uuestros ganados salgan del termino de Murçia porque en fe de nuestra parabla no recibades danyo ${ }^{53}$.

53. "Et rogamos a los dichos ommes buenos que touiesen por bien e que mandasen, eso mesmo, reuogar el pregon que fecho auian por que nos ouiesemos lugar de tractar entre uos e ellos paç e sosiego, segund començado lo auiemos e que lo fasçiesen luego o que sacasen a nos de uerguença que nos asi lo auiemos prometido a uos quel dicho dia de sabado lo fariamos façer, et estos ommes buenos ouieron munchos acuerdos sobre ello, et este martes primero pasado, despues de uesperas, fiçieron este pregon segund ueredes por el treslado que enbiamos al procurador. Et si nos falleçiemos en lo que vos prometiemos rogamos vos que nos perdonedes, que Dios lo sabe, que non seria por no dar luengas e dilaçiones a estos omes buenos que lo quisiesen conplir, mas non se pudo ante façer por algunos enbargos que se y recresçieron.

Et omes buenos, segund paresçe por este pregon estos ommes buenos entienden que todos los uuestros uezinos saquen sus ganados del termino de Murçia e todos los bienes que y touieredes e esto façen por tener alguna pendra como uos fisçiestes en el çerrar de la puerta alla, que no pasen aca las mercadurias e diçen quel çerrar de la puerta de Murçia no es pendra a Horihuela e asi que uos quieren pendrar en cosas que uos sintades dellos e por esto quieren que los ganados salgan de su termino e todos los otros bienes de uezinos de Orihuela.

Et ommes buenos pues uos e el procurador començastes bien en estos fechos, de que nos tenemos en verdad de uos por muy encargado e obligado a uos e al procurador, rogamos uos que tengades por bien de tirar ese enbargo de la puerta, et nos trebajar nos hemos aca des que sopieremos que lo auedes 
La carta episcopal fue leída en el consell reunido en ese mismo día 10, y las consecuencias del rechazo de Murcia a las peticiones que les había transmitido el mediador y el fracaso de su misión no tardaron en aparecer, porque, además de dar cumplida respuesta a la misiva ${ }^{54}$, se ordenó la inmediata convocatoria para un consell general en el que se ordenó poner guardas y rondas en diferentes puntos de la población y término, mandadas por Pere de Riudolms, y se tomaron otras medidas extraordinarias ${ }^{55}$.

fecho porque estos ommes buenos reuogen del todo este pregon et las cosas tornen al primer estado. Et en esto tenemos que seruieredes a Dios e a los senyores de la terra que, loado sea Dios, nos auemos aquí nueuas de cada dia del rey, nuestro senyor, que es auenido con aquellos senyores sus parientes, et asi seruiçio e grand plaçer les faremos nos aca en auer entre nos paç e asosiego. Et de como touieredes por bien de façer, ayamos uuestra carta porque nos sepamos en como auemos de façer.

Otrosi, diçen nos que estos omes buenos que an fecho tornar los carneros de Jayme Uidal et si alguna cosa le fallesçe que no sea tornada, enbiat nos lo dezir e nos trebajar nos hemos con estos omes buenos que la fagan luego tornar.

Dada en Murçia, dieç dias de deçembre, Era de M CCC nouenta e dos anyos.

Et luego tenet por bien de dar recabdo por que los uuestros ganados salgan del termino de Murçia porque en fe de nuestra parabla no recibades danyo".1354-XII-10, Murcia. AMO, LA 1353-1356, A-1, ff. $70 \mathrm{v}-71 \mathrm{r}$.

54. En su respuesta el consell exponía a don Pedro como "les bons homens de Oriola que tenin bestiars en terme de Murçia auien e an pagat, mes de força que de grau e mes de feyt que de dret, per aquest any ques conplira per tot lo present mes de deembre asadura, montadgues e despres altres coses que ells de feyt e no de dret en[tenen imposar]", llegando las penas pecuniarias y prendas tomadas a alcanzar los "cinch mill morabetins, les quals coses penyores fon feyts a gran injuria e perjudiçi dels uehins de Oriola que per dret e per costum antiga de tant de temps que memoria de omens no es en contrari, auien e deuen auer erbatges francament e lliura e sens alguna redempçio en terme de Murçia a llur bestiars coma xi mateix poguesen auer los de Murçia en terme de Oriola". Como se ve los consellers esgrimian antiguos derechos de pasto franco que tenian los de Orihuela cuando eran territorio castellano. Pedían un imposible y lo sabían, por lo cual, apostillaban: "Per les quals coses, senyor, a uos per les presents soplicam e clamam merçe si les coses per uos a nos requestes no son conplides que us ajats per escusats car nos sens restituçio primerament feta dels que dit es non hi porien auenir car molt romanim dampnificats per les dits greuges e altres que cascuns de nostres uehins reeben de homens de Murçia sens tota raho". 1354-XII-12, Orihuela. AMO, LA 1353-1356, A-1, ff. 71v-72r. Bellot 2001, 2, pp. 245-246.

55. "En lo dit dia en continent ... anaren al proch de la cort e engeraren consell jeneral on foren justats ab tronpeta. En lo qual foren los honrrats en Bernat Carles, tinent lloch del honrrat en Garçia de Llerin, justiçia de Oriola per el alt senyor infant don Ferrand etc., et en Berenguer de Lliminyana e en Bertomeu Morrelles e en Jacme Carbonell, jurats, et escuders e homens de paratge e honrrats de uila, segons acostumada manera. Et en lo dit consell, per seruei del senyor infant e a guarda del lloch, fon ordenat que rondes e guaytes sien posades e meses en la uila, es a saber, VIII guaytes cada nit, dues a la porta de Murçia e dues a la porta noua, et quatre rondes les dues de prima e dues de mija nit dauall. Et aquell a qui lo consell ho comanara que les do a tants dies com per bons homens fa acordat per compte çert e no a mes. Et que do albara lo calendari a cascu de aquells a qui le manara cascua uegada per que sia çert aquell qui aura a fer la roda e la guayta qual dia la feu. Et quel que guaytar sera no la pusca donar abans del temps que per los comptadors que el consell y posara sera atrobat al qual compte a fer $\mathrm{e}$ signa lo consell ab los jurats en sera pres. En Johan Badenes, en Guillem Agullana, fuster, e en Guillem del Castellar, en Bernat Ceruer, en Domingo Orumbella, uehins ... Et en lo dit consell, en presençia del poble, nomenaren per manador de rondes e de guaytes per tant de temps com lo consell uolrra e li plaura e non pus an Pere de Riudolms, vehi del dit lloch qui present hera, al qual lo dit consell mana en pena de mill soldes que reeba lo manament e do bon recapte, lo qual dit Pere de Riudolms ... el dient reebe lo dit manament. Et que jura per Deu e per les sants quatre euangelis... 
Un paréntesis en el conflicto se abrió cuando el infante Fernando respondió a la carta que el consell le envió para notificarle la situación existente con Mur$\operatorname{cia}^{56}$, rechazando de plano las medidas del consell, pues siendo aliado de Pedro I, quien lo había nombrado Canciller Mayor de Castilla después de las vistas de

Atrosi, fon ordenat que a qual quier que le sera manat anar a la roda e a la guayta que aquella nit que manada li sera hi uaja personalment o que y trameta bon recapte per persones rahonables.

Atrosi, en lo dit consell ordenaren e establiren deu bons homs que daqui auant ab lo justiçi, jurats e sindichs ensemps tienguen e sien consell tota uia que mester sera, los quals ajen poder ab los dits justiçi, jurats e sindichs de dir e fer e ordenar e mercar e manar totes coses per tota la uniuersitat del consell que sien en seruiçi del alt senyor infant don Ferrando e prou e be del consell, los quals son aquestes que es seguexen: en Bertomeu Togores, en Jacme de Lliminyana, en Jacme de Masquefa, en Lop Garçia de Ayala, en Berenguer Morrelles, en Jacme Uidal, e Narnau Uermell, en Françesch Miro, en Pere Fraga, en Bertomeu Riufret, als quals lo dit consell dona e atorga poder conplit que tots deu o la major partida tota uia que sien ensemps ab lo justiçi, jurats e sindichs que puxen fer e tenir consell e puxen dir, fer, tratar, ordenar acabadament tots coses que sien en seruiçi del dit senyor infant e a prou e be del dit consell. Et promesen auer per firme e per estable en per tots temps tot quant per ells o la major partida de ells ab los dits justiçi, jurats e sindichs ensemps sera dit, feyt, rahonat, tractat, endreçat, ordenat, congitat, negociat en seruir del dit senyor infant et prou e be del consell et james non reuocaran nyn uendran contra". 1354-XII-10, Orihuela. AMO, LA 1353-1356, A-1, ff. 69v-70r.

56. "Primerament, senyor, uos fem saber quel honrrat en Johan Sanchez de Ayala, procurador uostre en esta partida, ha fechs tancar les portes d'Oriola als uehins de Murçia ab crida publica de la qual dins clausura de aquesta carta uos trametem tresellada. Et jatsia, senyor, [que] per algunes uegades ajam usat del dit tancament contra omens de Murçia per que nos uolien uenir a esmena sobre molts e diuerses greuges quens fahien per escusar perills e dampnatges de penyors. Empero, senyor, esguardat lo temps que tenim e lo estament e condiçio de la terra et dels uostres sotsmeses qui açi en esta partida son et considerades altres coses molt pertanyet de aquest feyt les quals, senyor, per carta non podem trametre a dir remet perills de camins trobam, senyor, saluar tota uegada la uostra altea e honor deure saui consell que el tancament de les ports quant al present temps que pot tornar mes a deseruey uostre e dan de uostres sotsmeses que ans deu seruir uostre ni a profit de algu per moltes rahons que [respon] declarar. Encara, senyor (borrado), que el consell (borrado) sobre aquest (borrado) a dir e fer saber al rey de Castella et tots menys feren embargar semblant ordenadament e foragitaren de Murçia e de llurs termes totes persones e bens qui fosen de homens de (sic) Oriola ab inposiçio de penes que si daquí auant y eren atrobats que foren retenguts per que daquell fos feyt ço quel rey manas, per la qual cosa tots los bestiars qui eren en llur senyoria son ahuts a exir e a tornar en terme de Oriola on uiuen e pasen llurs temps al millor que poden. E axi, senyor, com totes coses ajen temps et temps no aja tots coses per ço auisitam uos de aquestes afers per tal que uos, senyor, y proueescats ço que sia merçe e seruei uostre e profit e be dels uostres sotsmeses et lo per tant, senyor, que si uos, senyor, entenets que per aquest tancament de ports se pusca a uos enseguir seruey e honor que no solament ab aquest tancament mas encara ab les persones e ab tot quant auem, som apparellats de conplir e exseguir uos manaments e de morir per uos e per uostre seruei e per exalçament de uostra honor". En espera de la respuesta del infante, el consell siguió adoptando medidas de apercibimiento y defensa, ya que en la sesión del 16 de diciembre, acordó que "fosen feytes deenes de tots les jents de la uila e de la orta, a les quals deenes a fer manament que fossen asignats de cascuna parroquia deu bons homens es a saber, de Sant Saluador en Pere Miro e en Pere Argençola, et de Santa Justa Nalfonso de Lliminyana e en Domingo And[reu], et de Sant Jacme en Pere, notari, e en Bertomeu Riufret, als quals lo dit consell dona poder que façan deenes e caps de deenes de tots les hauitants de la uila. Et, atrosi, que a tots aquells que ells conexiren que se oferit o puxen quels manen tenir dues armes, quels liuren tots les penes que les tinguen a tots sos [borrado] e be en conç e de lo que mester e neçesari es et dintre dia çert. Et atrosi, que sia uist e conegut per ells que ells poran tenir e mantenir lança e tenir ab escut, quels manen, so çerts penes, que tinguen dia çert", para lo cual se enviaron correos a todos los lugares de la huerta para que hicieran lo mismo. 1354-XII-14, Orihuela, y 1354-XII-16, Orihuela. AMO, LA 1353-1356, A-1, ff. 72v-73v. 
Tejadillo en $1354^{57}$, no podía sostener la postura de sus vasallos con respecto a Murcia y, por otro lado, esta decisión afectaba a la clerecía episcopal que tampoco podría entrar en Orihuela y este hecho influiría negativamente en la resolución del entredicho en el que estaba incursa la localidad. Por todo ello, desde Toro, escribió al consell una carta conciliadora, para notificarles que había ordenado a Juan Jiménez de Perencisa que abriese las puertas de inmediato y sin excusa ${ }^{58}$, decisión a la que contribuyó la llegada a Orihuela del obispo Alfonso de Vargas, pues hubiera sido muy grave que no dejasen entrar al titular de la sede a la que pertenecían, lo que sólo podía traer nuevos castigos y censuras espirituales que causaban verdadero desasosiego entre los fieles, y que llegaba decidido a poner solución al problema de la falta de entendimiento con los oriolanos y retomar la función mediadora entre Murcia y Orihuela que había dejado inconclusa el obispo de Coria cuando marchó a su diócesis.

El 31 de enero de 1355, el acceso a Orihuela quedó despejado tras el pregón de un acuerdo del consell en que se insistía que la medida se hacía per be de asosech et ab esperança que algunes greugues feyts per los de Murçia als de Oriola seran restituits e redimits a degut estament ${ }^{59}$. Alfonso de Vargas, como su antecesor,

57. Ocupó el cargo hasta su ruptura con el monarca castellano, es decir entre 1454 y 1457. López de Ayala 1779, pp. 157-161; Ramón Pont 1983, p. 65; Salazar y Acha 2014, p. 315.

58. La carta del infante decía así: "Infant don Ferrando, fill del molt alt senyor en Alfonso, de alta recordaçio, rey de Arago, per la graçia de Deu, marques de Tortosa e senyor de Aluarrazin. Als feels nostres los prohomens, consell e uniuersitat de la ula nostra de Oriola, salut e graçia.

Fem uos saber que reebem uostra lletra e les coses en aquella contengudes enteses uos responem que us tenim en seruei ço que en la dita uostra lletra nos trametets a dir et creem que tanta es la uostra lealtat de la qual plenarament confiam, que de tota cosa que fos nostre seruey e honor nos curariets clarament informar. Per que us dehim e manam que tota uegada que semblants coses sapiats nos ne çertifiquets llargament per lletra uostra.

Al tals quens fets saber en raho dels portes tancades, nos enuiam manar al amat conseller nostre e batlle general de ço que nos auem en partida del regne de Valençia, Johan Ximenez de Perençisa, que en continent faça obrir les dits portes, tota excusa apart posada.

Dada en Toro, a IX dies de jener, anno a Natiuitate Domini $\mathrm{M}^{\circ} \mathrm{CCC}^{\circ} \mathrm{L}^{\circ}$ Quinto. Subscrip.

AMO, LA 1353-1356, A-1, f. 78r. La cuestión del cierre de las puertas tratada también por Bellot 2001, 2, p. 245; Ramón Pont 1983, p. 73.

59. La medida, es cierto, se tomaba en acatamiento de la orden del infante y en honor de don Alfonso de Vargas, pero también lo es que beneficiaba al abastecimiento de Orihuela, ya que todos los mercaderes que quisieran acudir a la capital de la Vega Baja, lo podían hacer con seguridad tal y como sucedía antes del cierre de las puertas: "Ara ajats que us esser hom a saber de part dels honrrats procurador et batlle general que com la porta de Oriola fos a tro al present dia tancada als de Murçia et a altres per çertes rahons en la crida del cerrament contengudes, el honrrat in Christo pare e senyor don Alfonso, per la graçia de Deu, bisbe de Cartagena, chançeller major de la senyora reyna e de [nuestro se]nyor el infant don Ferrando, axi com a major ofiçial del dit senyor infant aja [tengut] per be pa(borrado) en si la abertura de la dita porta per be de asosech et ab esperança que alguns greuges feyts per los de Murçia als de Oriola seran restituits e redimits a degut estament. Et por po[sar] en la terra aquelles obres que cunplen a pare spiritual, los dits ofiçials del senyor infant per dar honrra al dit senyor bisbe en la sua benauenturada uenguda que ara feu a Horiola e dels dits senyors rehina e infant, ajen acordat en senps ab lo dit senyor bisbe que la dita porta se obra ara de continet et la ajen vberta. Per ço manen que los camins e mercadors e altres quals seuol quiera ab ses mercaderies e bens vajan axi segurs et per tal manera com solien anar en temps quel dit çerrament nos fa. Per que manen a tot hom que aço guart en pena de la merçe del senyor infant e guart se qui a guardar sia". Ibid. f. 78r-v. 
recibió un memorial en el que se contenían todos los agravios que los de Orihuela decían que ocasionaban en Murcia, con objeto de que lo transmitiese al concejo murciano y que también fue pregonado para conocimiento general el mismo día 31 de enero, por el pregonero Pere Vicenç. En él los miembros del consell exponían sus reivindicaciones, centradas en las exigencias impositivas que les hacían en territorio murciano y que afectaban fundamentalmente a los ganados, apresamientos y confiscaciones de rebaños, al tráfico ilegal y a la pesca.

En primer lugar, la ruptura de la costumbre antigua que permitía que los rebaños de Orihuela pudiesen pastar en el Campo de Cartagena libres de impuestos, pues alli los recaudadores concejiles murcianos exigían de poch de temps a ença que los vehins de Oriola peixen ${ }^{60}$. El cobro de un derecho por cabeza, asadura y montadgo era la triple vertiente de la segunda queja, pues ya en Orihuela en la época de la campaña contra Granada de Alfonso IV el propio rey impuso el cobro de impuestos mientras durase la guerra para financiarla, pero en Murcia lo seguían cobrando y exigían que lo dejasen de pedir, pues los ganaders directament ni indirecta ni la cosa publica no alcançen nengu profit ${ }^{61}$.

El problema del servicio de los ganados, consistente en una cuantía de cinco reses de cada mil de ganado ovino, tres por cada millar de bovino y una cabeza por cada cien de porcino, parece que ya existía en tiempo de Alfonso $\mathrm{X}^{62}$ y pronto se unió al montazgo, para formar el llamado "servicio y montazgo" que, efectivamente, pagaban los rebaños que llegaban desde largas distancias al Campo de Cartagena y los de Murcia estaban exentos, siempre que su dueño fuese vecino de la capital y lo mismo sucedía en otros términos concejiles, pero los de Orihuela se quejaban, creo que sin razón porque sus ganados se consideraban "travesíos"

60. "Primerament, senyor, que saben be los homens bons de Murçia que antigament e en tro hara de poch de temps a ença que los vehins de Oriola peixen per sos ganados les herbes del Camp de Cartagena et per lo terme de Murçia sens que pechos ni altre dret no les hera demanats". Ibid. f. $78 \mathrm{v}$.

61. "Item, ara de algun temps ença el rey don Alfonç, a qui Deus perdo, per los mesters dels guerres que auia ab los moros posa algunes carregs sobre los ganados et quant en aço entenen los de Oriola que de que la guerra duras e fos comuna carrega a tots que ells lo deuen auer per tollerable, pero els de Murçia anen e sots color de fer abus o per als pous (sic) esforçen se posar nou uechtigal o manera de exacçio o pecho et allo conuerterehen en els tres vsos propios en los quals los ganaders directament ni endirecta ni la cosa publica no alcançen nengu profit. E tals coses encara por los prinçeps son reprouades e no les poden fer sens pectat. E tirania molt menys do (roto) no deue esser consentit en poble de qual seuol condiçio sia, per que demanem [los de ] Oriola que el dit dret per cabeça e el montadgo e asadura, los quals pechos se bene[fiçian de] la manera inprouada que diu este capitol, que sien relleuats per los de Murçia (borrado) car no (borrado) per que les dits pechos (borrado) les veins de Oriola (borrado)". Ibid. ff. 78v-79r.

62. Además existía también un pago en metálico por cada tipo de reses, y el ganado bovino debía abonar 18 maravedís de "guarda", 3 maravedís el ovino y un dinero por cabeza el ganado de cerda. En Castilla, el servicio se unía al montazgo, y el ganado que permanecía todo el tiempo en el término de la localidad en donde era vecino su dueño estaba exento del pago del impuesto, que gravaba fundamentalmente a los rebaños cabañiles, es decir los trashumantes, los que cruzaban los puertos, y los denominados "travesíos", ganados también trashumantes, pero que realizaban desplazamientos mucho más cortos que los anteriores, generalmente sin salir de un extenso territorio de un mismo concejo o de varios colindantes, como era el caso de Murcia y Orihuela, y su destino era generalmente la dehesa concejil. Todos pagaban en especie en carneros con lana o, en su defecto, ovejas paridas con sus crías. Ladero Quesada 2009, pp. 151-152, 156 y 158-159. 
y procedían, además de un reino diferente, y alegaban en defensa de su posición que los recaudadores en lugar de exigir su pago a todos los vecinos del obispado de Cartagena, sólo lo cobraban a los ganaderos oriolanos y, por ser greuge injust se pertany esser relleuat ${ }^{63}$.

El consell recogía las quejas de sus vecinos, dueños de ganado mayor, por lo que consideraban abusos de los recaudadores del diezmo que se cobraba en Murcia y alegaban que sólo debían pagar las reses merchaniegas, es decir las que se llevaban a vender a ferias y mercados y no otras, ya que tenían que pagar por toda bestia que entrasen en término murciano, fuesen merchaniegas o no ${ }^{64}$.

Junto a estas cuestiones tributarias, había otra causa de queja referente a los agravios que recibían los vecinos de Orihuela por apresamientos de reses, sobre todo bestias y entre ellas mulas y mulos, en tierra murciana, sin causa justificada y sin dar explicaciones al respecto ${ }^{65}$.

Muy relacionada con el punto anterior, pues los guardas de las sacas situados en los pasos fronterizos tenían mucho que ver en muchos de esos apresamientos de bestias, está la siguiente reivindicación del consell, porque los oficiales del alcalde de las sacas post posada tota raho e manera an escorcollats axi fembres como homens e algunes no ben tractats, y es que no eran pocas las ocasiones en las que los registros se hacían con muy poco respeto, sobre todo con las mujeres, cosa que no era exclusiva de las procedentes de territorio aragonés ${ }^{66}$. Se trataba de algo que había que corregir pues se podía saber lo que portaban los afectados y en qué condiciones sin quebrar el honor de las personas ${ }^{67}$.

63. "Item (borrado)menan de los ganados de los de Oriola seruiçi dins lo bisbat de Cartagena lo qual no pa (borrado) homens que toman de veins que sien del dit bisbat sino los de Oriola per que es aquest (borrado) greuge injust se pertany esser relleuat". AMO, LA 1353-1356, A-1, f. 79r.

64. "Item, senyor, pagam delme cascun any e las cabanyes dels bestiars de omens de Oriola. Et la carta que els arrendadors an del rey no mana pagar sino als ganados merxannegos que ixen de (borrado) foren on es uist esser tenguts pagar lo dit delme". Ibid.

65. "Item, que an pres e acabanyar poch dies ha de diuerses cabanyes de omens de Oriola de cascuna manada de bestiar. Et aço no sabem la raho per que ho an feyt com no la uullen dir o declarar". Ibid.

66. En el concejo del 2 de agosto de 1399 se expuso como sucedía que "muchos que se nonbran guardas, asy del almoxarifadgo como de las sacas et cosas vedadas et estos a tales que se ponian en el camino de Molina, que es camino castellano e que descorcollauan a los moros et avn a las moras fasta les fazer mostrar las tetas e avn sus vergueñas, et que esto que era a muy grant desonrra de la çibdat en consentir las dichas cosas, ende mas a los moros que trahen a la çibdat trigo e çeuada e leña e carbon et otras vituallas para mantenimiento et prouision de la dicha çibdat". Por esta razón, el concejo ordenó que los jurados mandasen a los almojarifes y alcalde de las sacas que "pongan tales guardas porque la dicha çibdat sea dellos contentos e ellos ayan su derecho de lo que fuere tomado por las dichas guardas et que las dichas guardas que asy pusieren que las escriuan et manifiesten en poder del escriuano del concejo porquel dicho conçejo vea sy son pertenesçientes para ello et estas tales guardas de las sacas que esten a los mojones et las guardas de las aduanas que esten a las puertas do es acostunbrado, e sy fizieren lo que no deuen que se paren a ello". AMM, A.C. 1399-1400, f. 35r.

67. "Item, be conexem los de Oriola que les trets de moneda e de les coses uedades que an mester guardes per que en aço an querella los de Oriola en quant post posada tota raho e manera an escorcollats axi fembres com homens et algunes no ben tractats. Et tan prop es uehinatge de Oriola a Murçia que les conexen les diçios los vns als altres. Et axi poria esser guardada honrra a cascu axi com per uertut de sagrament o per altra honor sera manera sabuda ueritat de ço que porten, per que es notori 
Un aspecto que también generaba controversia era la prohibición murciana de que los pescadores oriolanos pescasen en la albufera de Cabo de Palos, en clara vulneración del derecho natural que afectaba a todos los hombres y que estaban obligados a cumplirlo, dado el carácter comunal de los animales marinos ${ }^{68} \mathrm{y}$, en consecuencia el consell reclamaba su derecho a pescar libremente en el espacio de Cabo de Palos ${ }^{69}$, que Murcia consideraba que era suyo y la pesca explotada por sus propios pescadores y trajineros para abastecimiento de la ciudad en exclusiva ${ }^{70}$.

El prelado recibió el memorial del consell y también escuchó las consideraciones que se le hicieron sobre su contenido y, señala Bellot, que el concejo de Murcia le entregó otro con las alegaciones que tenían respecto a Orihuela, y continua diciendo que con su autoridad se sosegó todo por entonces ${ }^{71}$. Pero la tranquilidad no duraría mucho tiempo, pues los agravios injustificados unas veces y otras en represalia de hechos semejantes acaecidos en el territorio oriolano a vecinos de Murcia y viceversa, continuaron y la escalada en estas acciones durante los primeros meses de 1356 en los que el consell se vio afectado en varios frentes ${ }^{72}$,

que los de Oriola en la dita raho fon agreuiats, et axi es mester conogiment en lo dit negoçi. Et si dien los de Murçia que aço esta en los ofiçials del rey, de aço ha rahon bona que les de Murçia o poden fer mellorar ab los ofiçials ho suplicar al rey com los de Oriola donarien recapte en tal cas". AMO, LA 1353-1356, A-1, f. 79r.

68. En época clásica Ulpiano definió el Derecho Natural: "ius naturale est quod natura omnia animalia docuit; nam ius istud non humani generis propium, sed omnium animalium, quae in terra quae in mari nasciuntur, avium quaoque commune est. Hinc descendit maris atque feminae coniucto, quam nos matrimonium apellamus, hinc liberorum procreatio hinc educatio; videmus etenim cetera quoque animalia, feras etiam, istius iuris peritia censeri”. Ese mismo planteamiento siguió San Isidoro, para quien el Derecho Natural englobaba "la unión sexual, la procreación y educación de los hijos, una cierta comunidad de bienes, la libertad en general, la adquisición de bienes del mar, tierra y aire, la devolución de lo prestado y la legítima defensa", principios que perdudarían durante toda la Edad Media, Vid. Asis Roig 1958-1959, pp. 150-151; Ayala Martínez 2003, p. 381; Carpintero Benítez 1981, pp. $68,69,73.76-79,87$.

69. 'Item, ay encara molt nouell greuge que com la mar e tots les circunstançies de la mar e encara iura? maris sien de dret natural al qual nos pot mudar ni corromper per nengu dret ciuil axi comun a tots los homens per tal manera que vn no pot uedar a altre lus de les dites coses que los de Murçia (agora) es façen se uedar a los de Oriola que no pexçen o que no porten del peix que pexcen en la albufera de Cap de Pals, la qual es contigua a la mar sens misteri e artifiçi de ome. Et an raho que per pexcar en aquell tots los homens de Espanya no seria dan ni interese a los de Murçia e no deuen eser oyts los de Murçia en aço com a aquells qui fon contra dret natural et desiguen (borrado) humane soçietatis e caritatis oure e a altri no donant profit a ells". AMO, LA 1353-1356, A-1, f. 79r.

70. Sirva como ejemplo el siguiente acuerdo del concejo de Murcia, tomado el 28 de agosto de 1406, a raíz de que "algunos pescadores, vezinos e moradores del reyno de Aragon, que son entrados a pescar et pescan en las mares del rey, nuestro señor, syn liçençia del conçejo ni del rey, nuestro señor, et todo el pescado que pescan que lo lieuan et enbian a vender a la tierra et señorio del rey de Aragon". Por ello, el concejo dispuso que el jurado clavario fuese " al lugar donde los dichos pescadores pescan e que les tome las xarçias et las barcas et si pudiere auer los dichos pescadores que los tome presos et los trayga aqui a la çibdat et los ponga en la prisyon". AMM, AC 1406-07, f. 69v-70r. Sobre la pesca en aguas murcianas, Torres Fontes 1987.

71. Bellot 2001, 2, p. 246.

72. En mayo de 1356, fueron apresados por gente de Murcia en termino oriolano 30 puercos a Juan Gilabert, vecino de Orihuela, y fueron llevados a Ceneta, mientras que el afectado compareció ante el consell para pedir justicia porque le habían devuelto 22, por lo que solicitó que se embargasen bienes de vecinos de Murcia que bastasen para cubrir el valor de los puercos que le fueron retenidos, no 
dejaba cada vez menos salida al entendimiento y estos conflictos se agravaron por el estallido de la guerra castellano-aragonesa, cuya causa principal, como señala el Profesor Cabuezuelo era:

el interés de Pedro I por recuperar las tierras que después de la sentencia de Torrellas pasaron a formar parte del reino de Valencia......Este móvil, silenciado en todo momento por el monarca castellano, es el más reiterativo de todos ellos... en las ententes o treguas que sucesivamente romperán el ritmo de la guerra. La recuperación del territorio en cuestión por parte de Castilla va a ser una constante durante toda la contienda, no escatimando ni en hombres ni en medios para lograrla ${ }^{73}$.

Pero el monarca castellano no consiguió modificar sustancialmente lo acordado en Torrellas que, como sabemos, permaneció, y en los tiempos futuros nuevos conflictos volverían a enrarecer las relaciones entre los vecinos de Murcia y Orihuela, además de que seguirían las tensiones entre la sede de Cartagena y los fieles oriolanos.

\section{CONCLUSIONES}

La sentencia de Torrellas anuló el Tratado de Almizra y llevó la frontera castellano-aragonesa al Segura, creando una zona limítrofe entre Murcia y Orihuela en la que al tratar las relaciones entre ambas, como ocurre también en otros espacios fronterizos muy diferentes a éste, hay que distinguir entre las que resultaban de la posición adoptada a nivel de reino de las manifestadas por la intencionalidad de los vecinos y dirigentes de las poblaciones cercanas a ella, que eran los que en mayor medida sentían las circunstancias que se derivaban de esa realidad. En el caso que trato el incremento de la tensión hasta la ruptura bélica es consecuencia de la política de Pedro I y su deseo de anular lo hecho en Torrellas, pues no hay duda de que ese era uno de los principales objetivos de la conflagración contra Pedro IV. El fracaso del monarca castellano y la actitud de su sucesor Enrique II, que se negó a entregar el resto del reino de Murcia al monarca aragonés quien no cesaba de insistir sobre ello, dejaron las cosas como estaban y ya no volvería a plantearse esta cuestión de la recuperación de las tierras perdidas o no ganadas en

sabía "per qual raho". La carta del consell a Murcia reclamando la devolución, 1356-VI-27, Orihuela, no obtuvo respuesta satisfactoria. En julio de 1356 eran los de Alcaraz quienes apresaban 110 cabezas de ovejas a García del Villar y Pere Ximenez del Val, en claro agravio porque ya habían pagado los derechos de montazgo, asadura y otros, también en Alcaraz, el 24 de julio, sufrió el embargo de 1.500 barceloneses de plata García Montáñez, vecino de Orihuela, sin que hubiese hecho nada para ello. AMO, LA 1353-1356, A-1, ff. 102v y 104r, 103r-v, 107v-108r.

73. Cabezuelo Pliego 1991, pp. 26-27. La bibliografía sobre este conflicto castellano-aragonés es relativamente abundante y se pueden destacar las siguientes obras, además de las de Ferrer i Mallol y Cabezuelo, ya citadas: Cabezuelo Pliego 2015; 2013; Ferrer i Mallol 2014; Gutiérrez de Velasco 1962; Lafuente Gómez 2009, 2012, 2014, 2017; Sánchez Martínez 2002. 
1304, según el lado del que se trate, al menos tal y como ahora, porque el siguiente conflicto castellano-aragonés entre 1420 y 1430, que también traería graves inquietudes a murcianos y oriolanos, tuvo un origen muy diferente y no pasó de ser una disputa "familiar" entre Juan II y su primo Alfonso V que fue resuelta sin dificultades en Majano.

Evidentemente, fueron las sociedades afectadas por la frontera de 1304 las que vivieron con toda intensidad los cambios sustanciales que trajo consigo la implantación de esa frontera física y tangible, que en adelante caracterizarían las relaciones entre Murcia y Orihuela en un plano muy distinto al que habían tenido cuando ambas ciudades pertenecían a Castilla. Pero junto a la divisoria dibujada por mojones existía otra mental en los habitantes de uno y otro lado que estaba aferrada a la realidad del pasado anterior a 1304 y que se ponía de relieve en varias ocasiones. La frontera murciano oriolana no era un espacio de inquietud permanente como sucedía con la granadina, pero sí de conflicto frecuente a causa del choque de intereses comunes, aunque contrapuestos, ya que en todo momento se mantuvo una clara intencionalidad de mantener la costumbre de tiempos anteriores que les beneficiaba, manifestada por las autoridades murcianas y oriolanas, caso de las exenciones impositivas a ganados y mercaderes o las que se debían respetar a los vecinos de ambas localidades tal y como se las había otorgado Alfonso X, como medio de evitar conflictos, pero la pertenencia de Murcia y Orihuela a reinos diferentes lo impedía en la mayoría de las ocasiones.

Una gran parte de los conflictos fronterizos guardan estrecha relación con la imprecisión del trazado de la divisoria que traería los problemas que los habitantes de uno y otro lado tendrían en el reino vecino cuyo término invadían, ya fuese por desconocimiento o ya por la insuficiente señalización, cazando, recolectando grana o realizando carbón vegetal. La resolución de estas cuestiones vecinales era doméstica y se lograba mediante el envío de cartas y mensajeros de uno y otro lado que tratasen la cuestión, salvo en etapas de tensión caracterizadas por las represalias en venganza del daño recibido, porque entonces las dificultades eran mucho mayores.

Otras transgresiones de la frontera tendrán mayores repercusiones, porque no faltaban los que conscientemente cruzaban el límite y se arriesgaban a ser apresados y embargados por los caballeros de la sierra y guardas, porque el resultado obtenido compensaba el riesgo que corrían. Eran los almogávares oriolanos que penetraban en territorio murciano y apresaban a musulmanes de las encomiendas santiaguistas o a los que transitaban por el término lorquino colindante con Xiquena y Vélez Blanco, zona frecuentemente visitada por ellos. Estas acciones implicaban a otros concejos como Lorca que era amenazado con los dirigentes de las localidades musulmanas cuyos vecinos habían sido capturados en el término lorquino, y por ello la presencia de procuradores enviados por los regidores de Lorca exigiendo su liberación es frecuente, ya fuese ante el concejo murciano o ante los miembros del consell. La actividad de los almogávares oriolanos en la frontera de Granada es una muestra del mantenimiento de uno de los objetivos que Aragón no logró en Torrellas y que era una aspiración desde la firma de Almizra que dejaba 
el reino nazarí fuera del alcance aragonés. En 1304 la frontera real se fijaba en la vega baja del Segura y era con el reino de Murcia no con el de Granada, lo que no era obstáculo para que el consell en más de una ocasión esgrimiese su posición "en frontera de moros".

El hecho de que una diócesis castellana tuviese jurisdicción sobre las tierras segregadas en Torrellas era también un factor de conflicto frecuente en el que se mezclaban las cuestiones políticas con las religiosas en su vertiente económica, porque las reticencias de las gentes de la zona oriolana a la hora de abonar las cantidades que como fieles estaban obligadas a pagar a la sede del obispado, además de las exigencias de los clérigos en su abono, y de otra parte el empeño de los clérigos en no contribuir a las derramas fijadas por el consell alegando que pertenecían a una jurisdicción diferente, provocaba la reacción hostil del vecindario oriolano y sus dirigentes. Esta situación también se producía en Murcia, pues la clerecía aducía también su fuero distinto para sustraerse al abono de tasas sobre el pescado y la carne puestas por el concejo para hacer frente, por ejemplo, a la reparación de muros y adarves, que si pagaban los restantes vecinos de la ciudad, lo cual motivó las protestas ante Alfonso XI que obligó pagar a los clérigos, porque si justo era que disfrutasen de la seguridad que proporcionaba el buen estado de la muralla, también lo era que contribuyesen a su mantenimiento.

Los efectos de Torrellas perduraron durante toda la Baja Edad Media y más allá como lo muestra la reiteración de hechos y problemas similares en diferentes épocas, debido a la persistencia de las causas que los provocaban cuya eliminación era imposible porque dirigentes murcianos y oriolanos tenían que defender los intereses de sus convecinos que muchas veces se oponían a los sostenidos en el otro lado, mientras que los causados desde el punto de vista eclesiástico desaparecieron casi totalmente tras la erección del obispado de Orihuela y la resolución de los conflictos generados por la adscripción de determinadas primicias y diezmos a la nueve sede.

\section{BIBLIOGRAFÍA}

Amasuno Sarraga, Marcelino V. (1994), “Cronología de la peste en la Corona de Castilla durante la segunda mitad del siglo XV", Studia histórica, Historia Medieval, 12, pp 25-52.

Arranz Guzmán, Ana (2001), "Las elecciones episcopales durante el reinado de

Pedro I de Castilla”, En la España Medieval, 24, pp. 421-461.

Arranz Guzmán, Ana (2000), "Pedro I ante los enfrentamientos entre los concejos y prelados castellanos", Anuario de Estudios Medievales, 30/1, pp. 235-276.

Asis Roig, Agustín de (1958-1959), "Sobre la problemática del Derecho Natural”, Anuario de Filosofía del Derecho, 6, pp. 150-151.

Ayala Martínez, Jorge Manuel (2003), "El Derecho Natural Antiguo y Medieval”, Revista Española de Filosofia Medieval, 10, pp. 377-386. 
Barrio Barrio, Juan Antonio (2008), "El campesinado en la frontera meridional del reino de Valencia. Del hambre de tierras y el autoabastecimiento a la búsqueda del beneficio y la especulación, ss. XIII-XV”, en Furió, Antoni; García-Oliver, Ferran (coords.), Pautes de consum i nivells de vida al món rural medieval, Valencia, pp. 1-36.

Barrio Barrio, Juan Antonio (2012), "La delimitación territorial y el control de los espacios en la frontera meridional del Reino de Valencia. Siglos XIII-XV", en Arízaga Bolumburu, Beatriz; Mariño Veiras, Dolores; Díez Herrera, Carmen; Peña Bocos, Esther; Solórzano Telechea, Jesús Ángel; Guijarro González, Susana; Añíbarro Rodríguez, Javier (eds.), Mundos medievales Espacios, sociedades y poder. Homenaje al Profesor José Ángel García de Cortázar y Ruiz de Aguirre, vol. 2. Santander, pp. 1053-1066.

Bellot, Pedro (2001), Anales de Orihuela, Torres Fontes, Juan (ed.), 2 vols. Murcia.

Cabezuelo Pliego, José Vicente (1988-1989), "En torno a la creación y funcionamiento de la Gobernación General de Orihuela", Anales de la Universidad de Alicante. Historia Medieval, 7, pp. 159-180.

Cabezuelo Pliego, José Vicente (1991), La guerra de los dos Pedros en tierras alicantinas, Alicante.

Cabezuelo Pliego, José Vicente (1999), "Relaciones institucionales entre el adelantamiento del reino de Murcia y la procuración de Orihuela durante la época de la cruzada contra Granada (1329)", Historia. Instituciones. Documentos, 26, pp. 163-180.

Cabezuelo Pliego, José Vicente (2004), “Jaime II y la nueva articulación política y territorial del reino de Valencia, 1291-1308”, en Barrio Barrio, Juan Antonio (ed.), Los cimientos del Estado en la Edad Media. Cancillerías, notariado y privilegios reales en la construcción del Estado en la Edad Media. Alicante, pp. 181-196.

Cabezuelo Pliego, José Vicente (2010), “La proyección del Tratado de Torrellas. Entre el revisionismo político y la negación mental”, Medievalismo, 20, pp. 203-237.

Cabezuelo Pliego, José Vicente (2013), "Resolución del conflicto entre Pedro IV y el infante Fernando. Los acuerdos de Albarracín de 1357”, Anuario de Historia del Derecho Español, 83, pp. 733-774.

Cabezuelo Pliego, José Vicente (2015), "La guerra en el mar. La campaña marítima castellana de 1359 y la defensa litoral de la corona de Aragón”, eHumanista/IVITRA, 7, pp. 116-150.

Cabezuelo Pliego, José Vicente; Barrio Barrio, Juan Antonio (2005), "Las consecuencias de la Sentencia Arbitral de Torrellas en la articulación del reino de Valencia”, en La Mediterrania de la Corona d'Aragó, segles XIII-XVI. Centenari de la Sentència Arbitral de Torrellas, 1304-2004: XVVII Congrés d'Història de la Corona d'Aragó. Valencia, Vol. 2, pp. 2061-2076.

Canet Aparisi, Teresa (1983), "Los orígenes medievales de un impuesto moderno: La «quema»", Anales de la Universidad de Alicante. Historia Moderna, 3, pp. 181-190. 
Canet Aparisi, Teresa; Navarro Clerigues, Carles; Ribera Torrentí, María Antonia (1981-1982), "El impuesto de quema: Aproximación a su estudio", Estudis. Revista de Historia Moderna, 9, pp. 229-242.

Carpintero Benítez, Francisco (1981), "El Derecho Natural laico en la Edad Media. Observaciones sobre su metodología y conceptos", Persona y Derecho. Revista de fundamentación de las instituciones jurídicas y de derechos humanos, 8, pp. 33-100.

Carrasco Rodríguez, Antonio (1996-1997), "Los orígenes del pleito del obispado de Orihuela (Siglos XIII-XIV)", Anales de la Universidad de Alicante. Historia Medieval, 11, pp. 633-642.

Carrasco Rodríguez, Antonio (2001), La ciudad de Orihuela y el pleito del Obispado en la Edad Moderna, Alicante, Universidad de Alicante, (Tesis Doctoral).

Culiáñez Celdrán, Manuel Carlos (2015), Las relaciones de Orihuela con la frontera de Granada en el Siglo XV: La cautividad. Murcia, Universidad de Murcia, (Tesis Doctoral).

Diago Hernando, Máximo (2000), “La «Quema». Trayectoria histórica de un impuesto sobre los flujos comerciales entre las coronas de Castilla y Aragón (Siglos XIV y XV)", Anuario de Estudios Medievales, 30/1, pp. 92-115.

Estal Gutiérrez, Juan Manuel del (1982), Conquista y anexión de las tierras de Alicante, Elche, Orihuela y Guardamar al Reino de Valencia por Jaime II de Aragón (1296-1308), Alicante.

Estal Gutiérrez, Juan Manuel del, (1984), "Fueros y sociedad en el Reino de Murcia bajo la hegemonía de Aragón (1296-1304)", Anales de la Universidad de Alicante. Historia Medieval, 3, pp. 99-130.

Estal Gutiérrez, Juan Manuel del (1985-1990), El Reino de Murcia bajo Aragón. Corpus Documental, 2 vols, Alicante.

Estal Gutiérrez, Juan Manuel del (1990-1991), "El fuero y las Constituciones «Regni Murcie» de Jaime II de Aragón (1296-1301)”, Anales de la Universidad de Alicante. Historia Medieval, 7, pp. 19-56.

Estal Gutiérrez, Juan Manuel del (1996-1997), "El itinerario de Jaime II de Aragón en la conquista del reino castellano de Murcia (1296-1301)", Anales de la Universidad de Alicante. Historia Medieval, 11, pp. 173-200.

Estal Gutiérrez, Juan Manuel del (1998), "Vicisitudes del castillo santiaguista de Negra, en el reino de Murcia, bajo la Corona de Aragón (1296-1303)”, Anuario de Estudios Medievales, 28, pp. 75-96.

Ferrer i Mallol, María Teresa (1987), "Causes i antecedents de la guerra dels dos Peres", Boletín de la Sociedad Castellonense de Cultura, 63, pp. 445-506.

Ferrer i Mallol, María Teresa (1989), "La frontera meridional valenciana durant la guerra amb Castella dita dels Dos Peres", en Pere el Ceremoniós i la seva época. Barcelona, pp. 245-357.

Ferrer i Mallol, María Teresa (1990), Organització i defensa d'un territori fronterer. La governació d'Oriola en el segle XIV, Barcelona.

Ferrer i Mallol, María Teresa (2005), Entre la paz y la guerra. La Corona catalano-aragonesa y Castilla en la Baja Edad Media. Barcelona. 
Ferrer i Mallol, María Teresa (2014), "Els efectes de la guerra dels dos Peres (13561369). Abastament i fam a la governació d'Oriola", en Riera i Melis, Antoni (coord.), Guerra y carestía en la Europa Medieval, Lérida, pp. 129-148.

Gaibrois de Ballesteros, Mercedes (1928), Historia del reinado de Sancho IV de Castilla, III. Madrid.

García Isaac, José Marcos (2015), “La Paz de Almazán (1375): punto de inflexión en las relaciones castellano-aragonesas en el último cuarto del siglo XIV”, Historia Digital, 26, pp. 121-143.

García Samper, María (2007), “Aljibes en la frontera litoral castellano-aragonesa", Revista murciana de Antropología, 14, pp. 401-424.

García Sánchez, Expiración (2001), "Las plantas textiles y tintóreas en al-Andalus", en Marín, Manuel (ed.), Tejer y vestir: De la Antigüedad al Islam, Madrid, pp. 417-451.

González Arce, José Damián (2012), “De conjunto de rentas a impuesto aduanero. La transformación del almojarifazgo durante el siglo XIV en el reino de Murcia”, Anuario de Estudios Medievales, 42/2, pp. 669-696.

González Sánchez, Santiago (2013), Las relaciones exteriores de Castilla a comienzos del siglo XV: La minoría de Juan II (1407-1420), Madrid.

Gutiérrez de Velasco, Antonio (1951), "Los ingleses en España (Siglo XIV)", Estudios de Edad Media de la Corona de Aragón, IV, pp. 215-319.

Gutiérrez de Velasco, Antonio (1962), "La contraofensiva aragonesa en la Guerra de los dos Pedros. Actitud militar y diplomática de Pedro IV el Ceremonioso (años 1358 a 1362)", Cuadernos de Historia Jerónimo Zurita, 14-15, pp. 7-30.

Jiménez Alcázar, Juan Francisco (2008), “La incorporación de Mula a la Corona de Castilla: de la conquista a la contienda castellano-aragonesa de 1296-1304", Murgetana, 118, pp. 9-35.

Jiménez Alcázar, Juan Francisco (2010), "Relaciones interterritoriales en el sureste de la Península Ibérica durante la Baja Edad Media: cartas, mensajeros y ciudades en la frontera de Granada", Anuario de Estudios Medievales, 40/2, pp. 565-602.

Ladero Quesada, Miguel Ángel (2009), La Hacienda Real de Castilla, 1369-1504, Madrid.

Lafuente Gómez, Mario (2009), La Guerra de los dos Pedros en Aragón (13561366). Impacto y trascendencia de un conflicto bajomedieval, Zaragoza.

Lafuente Gómez, Mario (2012), Dos Coronas en guerra. Aragón y Castilla (13561366), Zaragoza.

Lafuente Gómez, Mario (2014), Un reino en armas: La guerra de los dos Pedros en Aragón (1356-1366), Zaragoza.

Lafuente Gómez, Mario (2017), “A la conquista de Aragón. La guerra de los dos Pedros (1356-1366)”, Desperta Ferro: Antigua y Medieval, 44, pp. 16-21.

Lemeunier, Guy (1997), "Drenaje y crecimiento agrícola en la España Mediterránea (1500-1800)”, Áreas. Revista Internacional de Ciencias Sociales, 17, pp. $31-42$. 
López-Amo Marín, Ángel (1956), "El derecho penal español de la Baja Edad Media", Anuario de Historia del Derecho Español, 26, pp. 337-368.

López de Ayala, Pedro (1779), Crónicas de los Reyes de castilla. Don Pedro, Don Enrique II, Don Juan I, Don Enrique III, I, Madrid, 1779.

Martínez Martínez, María (1995), "Organización y evolución de una sociedad de frontera: El reino de Murcia (ss. XIII-XV)", Medievalismo. Boletín de la Sociedad Española de Estudios Medievales, 5, pp. 31-88.

Martínez Martínez, María (2010a), La cultura del agua en la Murcia medieval (ss. IX-XIII), Murcia.

Martínez Martínez, María (2010b), "El paisaje del agua en la Murcia árabe (siglos IX-XIII)", Diálogos: Las noches de las tres culturas, Murcia, pp. 64-74.

Martínez Martínez, María (2011-2012), "El poder y la justicia del agua en la Murcia medieval: El Consejo de Hombres Buenos", Cuadernos de Historia de España, 65-66, pp. 459-466.

Marzal Palacios, Francisco Javier (2006), La esclavitud en Valencia durante la Baja Edad Media (1375-1425), Valencia, Universidad de Valencia (Tesis Doctoral).

Molina Molina, Ángel Luis (1978), "Documentos de Pedro I", Colección de Documentos para la Historia del Reino de Murcia, VII, Murcia.

Molina Molina, Ángel Luis (1996-1997), "El reino de Murcia durante la dominación aragonesa (1296-1305)", Anales de la Universidad de Alicante. Historia Medieval, 11, pp. 265-272.

Moxó y Montoliú, Francisco de (1982), “La relación epistolar entre Alfonso XI y Alfonso IV en el Archivo de la Corona de Aragón”, En la España Medieval, 3, pp. 173-196.

Ortuño Molina, Jorge (2011), "Definiciones identitarias y conflictividad en la Edad Media. Las relaciones de frontera entre los reinos cristianos de Murcia y Valencia en los Siglos XIII-XVI", Anuario de Estudios Medievales, 41/1, pp. 73-97.

Partearroyo Lacaba, Cristina (2005), "Estudio histórico-artístico de los tejidos de al-Andalus y afines", Bienes Culturales. Revista del Instituto del Patrimonio Histórico Español, 5, pp. 37-74.

Partearroyo Lacaba, Cristina (2007), “Tejidos andalusíes", Artigrama, 22, pp. 371-420.

Pascual Martínez, Lope (1976), "Notas para el Estudio de una institución: El alcalde-comisario de la frontera castellano-aragonesa", Miscelánea Medieval Murciana, II, pp. 229-275.

Pascual Martínez, Lope (1983), "Documentos de Enrique II”, Colección de Documentos para la Historia del Reino de Murcia, VIII, Murcia.

Ramón Pont, Antonio (1983), "El infante don Fernando, señor de Orihuela, en la Guerra de los dos Pedros (1356-1363)", Anales de la Universidad de Alicante. Historia Medieval, 2, pp. 63-92.

Real Academia de la Historia (1866), Cortes de los Antiguos Reinos de León y Castilla, III. Madrid. 
Rodríguez Peinado, Laura (2012), "La producción textil en al-Andalus: Origen y desarrollo", Anales de Historia del Arte, 22, pp. 265-279.

Sainz de la Maza Lasoli, Regina (1996-1997), "Los santiaguistas del reino de Murcia durante la ocupación aragonesa (1296-1304)", Anales de la Universidad de Alicante. Historia Medieval,11, pp. 273-300.

Salazar y Hacha, Jaime de (2014), "La cancillería real en la Corona de Castilla", en Sarasa Sánchez, Esteban (coord.), Monarquía, crónicas, archivos y cancillerías en los reinos hispano-cristianos: Siglos XIII-XV, Zaragoza, pp. 309-324.

Sánchez Martínez, Manuel (1981), "La contribución valenciana a la cruzada granadina de Alfonso IV de Aragón (1327-1335)", I Congreso de Historia del País Valenciano, II, Valencia, pp. 579-598.

Sánchez Martínez, Manuel (1993), “Guerra, avituallamiento del ejército y carestías en la Corona de Aragón: La provisión de cereal para la expedición granadina de Alfonso el Benigno", Historia. Instituciones. Documentos, 20, pp. 523-549.

Sánchez Martínez, Manuel (2002), “Un episodio de la Guerra de los Dos Pedros: la defensa costera de Cataluña en el verano de 1365", en Reglero de la Fuente, Carlos Manuel (coord.), Poder y sociedad en la Baja Edad Media Hispánica. Estudios en homenaje al Profesor Luis Vicente Díaz Martín. I, Valladolid, pp. 273-288.

Sanz Sancho, Iluminado (2002), Constituciones sinodales de la diócesis de Cartagena de 1323 a 1409, Murcia.

Serrano del Toro, Andrés (2015), El cautiverio en la frontera murciano-granadina en el siglo XV. Un fenómeno socio-económico, Murcia, Universidad de Murcia (Tesis Doctoral).

Torres Fontes, Juan (1951), "La delimitación del sudeste peninsular: TorrellasElche, 1304-1305", Anales de la Universidad de Murcia, IX, pp. 439-455.

Torres Fontes, Juan (1953), "El obispado de Cartagena en el siglo XIII”, Hispania, LII-LIII, pp. 339-401.

Torres Fontes, Juan (1956), "El entredicho del municipio de Orihuela en 1375", Hispania. Revista Española de Historia, 65, pp. 483-502.

Torres Fontes, Juan (1969), "Documentos del Siglo XIII", Colección de Documentos para la Historia del Reino de Murcia, II, Murcia.

Torres Fontes, Juan (1976), "Relación murciana de los López de Ayala en los siglos XIII y XIV”, Murgetana, XLV, pp. 5-35.

Torres Fontes, Juan (1977), "Documentos de Sancho IV" Colección de Documentos para la Historia del Reino de Murcia, IV. Murcia.

Torres Fontes, Juan (1980), "Documentos de Fernando IV”, Colección de Documentos para la Historia del Reino de Murcia, V, Murcia.

Torres Fontes, Juan (1981), "Tres epidemias de peste en Murcia en el Siglo XIV (1348-49 - 1379-80 - 1395-96)", en Torres Fontes, Juan; Casal Martínez, Federico; Mula Gómez, Antonio José; Ayala, José Antonio; Marset Campos, Pedro, De Historia Médica Murciana, II. Las Epidemias, Murcia, pp. 9-66. 
Torres Fontes, Juan (1986-1987), “El Tratado de Tarazona y la campaña aragonesa en el reino de Granada (1328-1330)", Roel, 7-8, pp. 3-19.

Torres Fontes, Juan (1987), "La pesca en el litoral murciano durante la Edad Media", en Nuestra Historia. Aportaciones al Curso de Historia sobre la Región de Murcia, Cartagena, pp. 113-127.

Torres Fontes, Juan (1990), "Murcia: la conformación de un reino de frontera", Historia de España Menéndez Pidal, Tomo XIII-I, Madrid, pp. 431-505. 1990.

Torres Fontes, Juan (1998), "Cronología de los obispos de Cartagena en la Edad Media", Anuario de Estudios Medievales, 28, pp. 661-677.

Torres Fontes, Juan; Molina Molina, Ángel Luis (2009), Fundamento de la Santa Iglesia y de toda la Diócesis de Carthagena. Murcia.

Torres Fontes, Juan; Torres Fontes, Cristina, (1984), "El campo de Lorca en la primera mitad del Siglo XIV", Miscelánea Medieval Murciana, XI, pp. 157-176.

Valdeón Baruque, Julio (1989), "La incidencia de la Guerra de los Cien Años en la Península Ibérica", en Pere el Ceremoniós i la seva época, Barcelona, pp. 47-57.

Valdeón Baruque, Julio (1996), Enrique II, 1369-1379, Palencia.

Veas Arteseros, Francisco de Asís (1985), "Documentos del siglo XIV -2-", Colección de Documentos para la Historia del Reino de Murcia, X, Murcia.

Veas Arteseros, Francisco de Asís (1997), "Documentos de Alfonso XI", Colección de Documentos para la Historia del Reino de Murcia, VI, Murcia.

Veas Arteseros, Francisco de Asís (2002), "Las relaciones entre el obispo y cabildo de Cartagena y Orihuela en el siglo XIV. El entredicho de 1354”, Littera Scripta in honorem Prof. Lope Pascual Martínez, 2. Murcia, pp. 993-1014.

Veas Arteseros, Francisco de Asís; Molina Molina, Ángel Luis (2015), "Documentos del Siglo XIV -1-", Colección de Documentos para la Historia del Reino de Murcia, IX, Murcia.

Veas Arteseros, Francisco de Asís; Serrano del Toro, Andrés (2016), "La actividad en el sector fronterizo de Xiquena", Revista de Estudios sobre Patrimonio, Cultura y Ciencias Medievales, 18, pp. 1259-1348. 